\title{
Influence of basin connectivity on sediment source, transport, and storage within the Mkabela Basin, South Africa
}

\author{
J. R. Miller ${ }^{1}$, G. Mackin ${ }^{2}$, P. Lechler ${ }^{1}$, M. Lord ${ }^{1}$, and S. Lorentz ${ }^{3}$ \\ ${ }^{1}$ Department of Geosciences and Natural Resources, Western Carolina University, Cullowhee, NC 28723, USA \\ ${ }^{2}$ Department of Mathematics and Statistics, Northern Kentucky University, Highland Heights, KY 41099, USA \\ ${ }^{3}$ School of Bioresources Engineering and Environmental Hydrology, University of KwaZulu-Natal, \\ Pietermaritzburg, South Africa
}

Correspondence to: J. R. Miller (jmiller@wcu.edu)

Received: 8 August 2012 - Published in Hydrol. Earth Syst. Sci. Discuss.: 6 September 2012

Revised: 16 January 2013 - Accepted: 24 January 2013 - Published: 21 February 2013

\begin{abstract}
The management of sediment and other non-point source (NPS) pollution has proven difficult, and requires a sound understanding of particle movement through the drainage system. The primary objective of this investigation was to obtain an understanding of NPS sediment source(s), transport, and storage within the Mkabela Basin, a representative agricultural catchment within the KwaZulu-Natal Midlands of eastern South Africa, by combining geomorphic, hydrologic and geochemical fingerprinting analyses.

The Mkabela Basin can be subdivided into three distinct subcatchments that differ in their ability to transport and store sediment along the axial valley. Headwater (upper catchment) areas are characterized by extensive wetlands that act as significant sediment sinks. Mid-catchment areas, characterized by higher relief and valley gradients, exhibit few wetlands, but rather are dominated by a combination of alluvial and bedrock channels that are conducive to sediment transport. The lower catchment exhibits a low-gradient alluvial channel that is boarded by extensive riparian wetlands that accumulate large quantities of sediment (and NPS pollutants).

Fingerprinting studies suggest that silt- and clay-rich layers found within wetland and reservoir deposits of the upper and upper-mid subcatchments are derived from the erosion of fine-grained, valley bottom soils frequently utilized as vegetable fields. Coarser-grained deposits within these wetlands and reservoirs result from the erosion of sandier hillslope soils extensively utilized for sugar cane, during relatively high magnitude runoff events that are capable of transporting sand-sized sediment off the slopes. Thus, the source
\end{abstract}

of sediment to the axial valley varies as a function of sediment size and runoff magnitude. Sediment export from upper to lower catchment areas was limited until the early 1990s, in part because the upper catchment wetlands were hydrologically disconnected from lower parts of the watershed during low to moderate flood events. The construction of a drainage ditch through a previously unchanneled wetland altered the hydrologic connectivity of the catchment, allowing sediment to be transported from the headwaters to the lower basin where much of it was deposited within riparian wetlands. The axial drainage system is now geomorphically and hydrologically connected during events capable of overflowing dams located throughout the study basin. The study indicates that increased valley connectivity partly negated the positive benefits of controlling sediment/nutrient exports from the catchment by means of upland based, best management practices.

\section{Introduction}

Although the impacts of point source pollution on aquatic ecosystems have been greatly reduced, the management of non-point source (NPS) pollution has proven to be extremely difficult, and is a leading cause of surface water degradation (USEPA, 2000). Non-point source pollutants are of particular concern in agricultural areas where sediment, nutrients, and pesticides may all negatively impact water quality. Attempts to control NPS pollution generally rely on the development and application of best management practices that balance the economic value of land-use activities with 
methods to reduce the production and influx of NPS pollutants to water resources. To be cost-effective, such management strategies require a sound understanding of the primary NPS pollutant sources, how pollutants are delivered to and transported through aquatic systems, and how various management scenarios will influence NPS pollutant loadings. While conceptually simple, development of quantitative tools upon which to base management decisions and strategies is complicated by multiple and diffuse sources of pollutants, their movement as both solutes and particulates, and differences in pathway transport dynamics over varying temporal and spatial scales. Fine-grained sediments serve as a particularly important component of the NPS pollutant problem because of their direct impact on biota, and the sorption of nutrients and other contaminants onto particle surfaces such that many hydrophobic contaminants are predominantly dispersed through river systems in the particulate form (Miller and Orbock Miller, 2007). It follows, then, that any attempt to effectively address NPS pollution requires a highly sophisticated understanding of the spatial and causal linkages among human activities, fine-grained sediment production, and sediment transport and storage processes over a range of time scales.

Historically, sediments (and associated pollutants) eroded from upland areas of a catchment were assumed to move semi-systematically through the drainage system to the basin mouth. This classical continuum view has begun to be replaced in recent years by a segmented, hierarchical perspective of a drainage network in which channel and valley floor environments can be subdivided into progressively smaller units (Frissell et al., 1986; Kishi et al., 1987; Grant et al., 1990, 1995; Montgomery and Buffington, 1993; Brierley and Fryirs, 2001, 2005; Miller et al., 2012). Each unit, of a given scale, is morphologically homogeneous with respect to landforms, processes, and other controlling factors such as geology, vegetation, and substrate (Gant et al., 1995). Common scales of study range from localized channel units (defined on the basis of various river bed features such as pools, riffles, bars, etc.), reach-scale units (defined according to the nature of both the channel and valley floor), and larger units ranging up to and beyond the entire drainage basin. Application of the hierarchal approach for management purposes has focused on reach-scale units, often referred to as process zones (Montgomery and Buffington, 1993; Miller et al., 2012).

Inherent within the hierarchal systems approach is the perception that process zones (as well as units defined at other scales) differ in their ability to produce, transport, and store sediment. A process zone therefore represents a fundamental unit of watershed management that allows distinct strategies to be developed for specific parts of the drainage network.

A closely related concept to the hierarchal view of a river system is connectivity. Connectivity, as used here, refers to the degree to which water and sediment can be transferred from one process zone to the next downstream zone (Hooke,
2003). The geomorphic and hydrologic connectivity of the system is highly dependent on the time scale under consideration. For example, drainage systems located in areas characterized by seasonal rainfall may be hydrologically connected during the wet period, but disconnected during the dry months when the channel possesses both perennial and ephemeral reaches (Miller et al., 2012). Over longer time scales (years to decades), sections of the drainage network may become incised, thereby increasing the surface connectivity between the zones, or become filled, creating a discontinuous drainage system with decreased connectivity between process zones.

In light of the above, the movement of NPS pollutants through a drainage system will not only depend on existing hillslope conditions and management practices, but on the hierarchal structure (morphometry) of the watershed and the connectivity between process zones and other hierarchal units. The primary objective of this paper is to describe spatial variations in the source(s), transport, and storage of sediment over annual to decadal time scales within the Mkabela drainage basin, a representative catchment within the KwaZulu-Natal Midlands of eastern South Africa. The utilized analysis integrates field and cartographic data of fluvial landforms and processes with detailed geochemical analyses of sediment provenance. The latter analyses allow for the quantification of long-term (decadal-scale) changes in sedimentation rates and basin connectivity along the axial drainage system.

\section{Study area: geologic, geographic and climatic characteristics}

The Mkabela Catchment is located within the KwaZuluNatal Midlands of eastern South Africa, approximately $25 \mathrm{~km}$ from Pietermaritzburg (Fig. 1). The Mkabela River basin was selected for study because (1) it is representative of catchments in the region in terms of size, relief, underlying geology, and land use, and (2) is a tributary to the much larger Mgeni River that drains most of the Midlands, and for which a decline in water quality, by means of eutrophication, has been an increasing concern. Important nutrient sources include direct waste water inputs, broken sewer lines, animal wastes, and non-point source inputs, particularly sedimentassociated nutrients from agricultural lands.

Climatically, the Mkabela Basin is characterized by semiarid conditions, receiving on average $890 \mathrm{~mm}$ of precipitation per year, greater than $80 \%$ of which falls during the summer months of October to March. Temperatures, measured between 2005 and 2009, ranged between 4 and $44^{\circ} \mathrm{C}$. Ecologically, the basin and surrounding area are characterized by savannah type vegetation (referred to as the Savannah Ecoregion; WRC, 2002), although land cover has been dramatically altered during the past century. Historically, land use within the basin was utilized for forestry (pine, wattles, gum), 


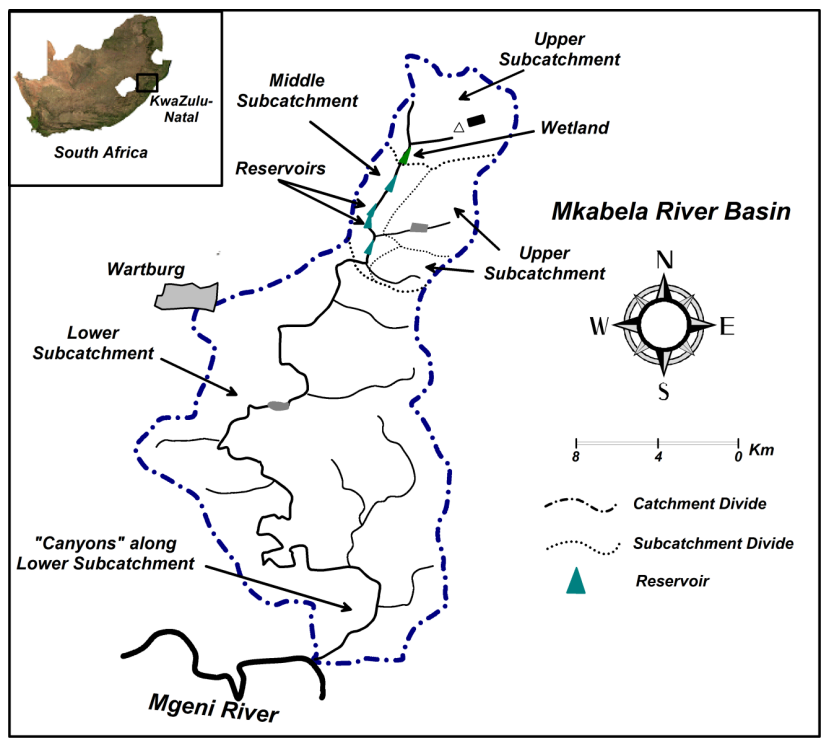

Fig. 1. Map showing the location of the Mkabela Catchment in South Africa and the position of the defined subcatchments within the basin.

pasture and dairy operations, and maize. Significant areas of the catchment were converted to sugar cane in 1968 to 1970. Current land use varies between three morphologically distinct catchment areas, referred to as the upper, middle (or mid), and lower subcatchments (Fig. 2). Land use within the upper subcatchments is dominated by sugar cane on hillslopes, and pasture (grasslands), maize and other vegetables on valley floors. Forested areas of wattle and pine are also present on upland areas locally. The middle subcatchment is dominated by sugar cane on hillslopes and pastures (grasslands) on the valley bottom (Fig. 2). Valley bottom wetlands are common within the upper catchments, and are replaced in mid-catchment areas by riparian wetlands and channelized alluvial valleys periodically interrupted by dams and reservoirs, most of which were constructed between 1970 and 1980 (the downstream most reservoir within the study area, Fig. 1 was build in 1950). The lower subcatchment is characterized by forested riparian wetlands on the valley floor and hillslopes that are predominantly covered by sugar cane vegetation.

The basin as a whole is underlain primarily by shales, siltstones, and red sandstones of the Natal Sandstone and, to a lesser degree, the Dwyka Groups. Nine soils types have been described in sediments overlying the bedrock including Avalon, Cartref, Clovelly, Glencoe, Glenrosa, Hutton, Katspruit, Longlands, and Westleigh (Fig. 3).

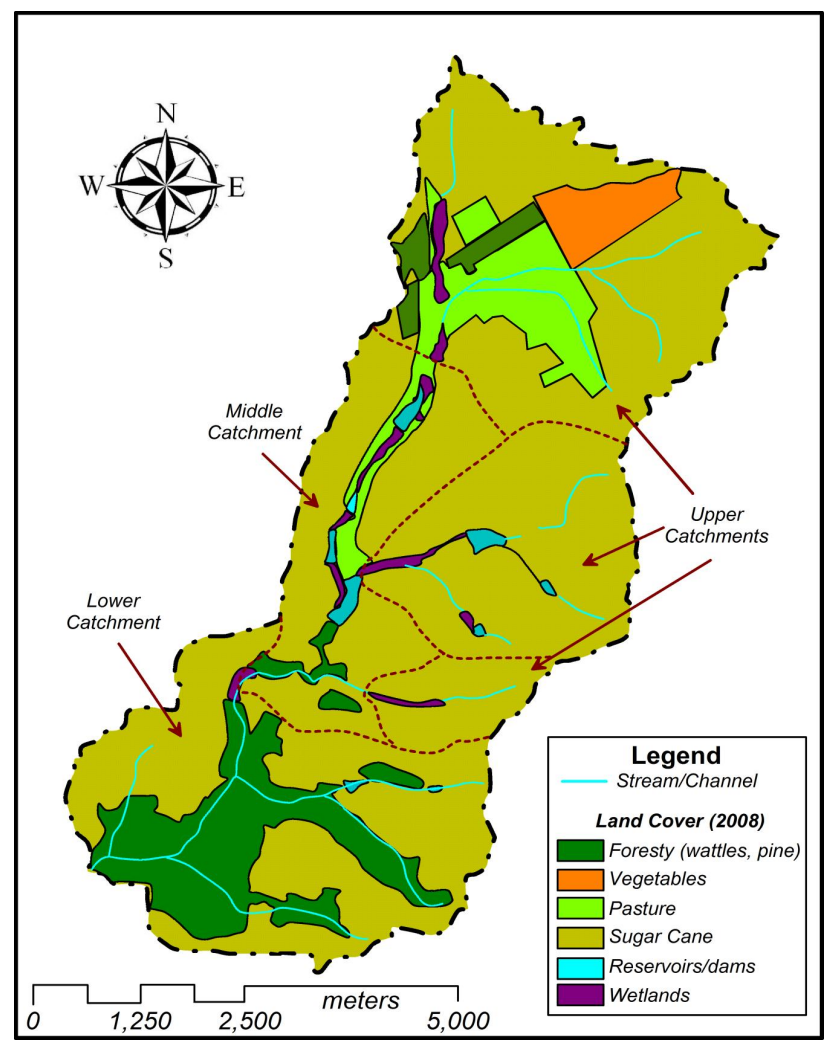

Fig. 2. Map showing distribution of observed land-use types within the Mkabela Catchment (modified from Lorentz et al., 2011).

\section{Methods}

\subsection{Process zone mapping and characterization}

Field and cartographic observations indicated that the catchment could be subdivided into distinct process zone and subcatchment areas (Figs. 1, 4 and 5). Subcatchment areas were defined according to changes in hillslope and valley morphology (e.g., gradient, width), whereas the processes zones represent stream reaches defined on the basis of their position on the landscape, their dimensions and cross-sectional form, the composition and nature of the bounding materials (bedrock vs. sediment; sediment size, stratification, etc.), and the relief/gradient of the channel and surrounding terrain. It is important to recognize that while zone types were defined geomorphically, each type exhibits specific traits with regard to geomorphic processes (including erosion and deposition) operating within the channel, and hydrologic sources and sinks (Table 1).

Delineation and mapping of process zones utilized an iterative approach where distinct reaches of the drainage network were classified and mapped on 2007 georectified SPOT images, with the aid of stereoscopic viewing of 2004, $1: 10000$ aerial photographs. Once mapped, the georectified and locally field-checked data provided spatial information 
Table 1. Summary of process zones and their general characteristics.

\begin{tabular}{|c|c|c|c|c|}
\hline & $\begin{array}{l}\text { Process } \\
\text { zone }\end{array}$ & Morphology & Sediment storage & Dominant process(es) \\
\hline \multirow[t]{3}{*}{$\begin{array}{l}\text { Process } \\
\text { zones in } \\
\text { low order } \\
\text { valleys }\end{array}$} & Waterway & $\begin{array}{l}\text { Wide, shallow, often } \\
\text { u-shaped man-made } \\
\text { channels; channel } \\
\text { oriented parallel to slope; } \\
\text { bed and banks typically } \\
\text { covered in vegetation }\end{array}$ & $\begin{array}{l}\text { Minimal sediment } \\
\text { storage in bed of } \\
\text { waterway }\end{array}$ & $\begin{array}{l}\text { Minor sediment } \\
\text { production; dominated } \\
\text { by sediment transport } \\
\text { over "rough" bed; } \\
\text { Hydrologically, a zone } \\
\text { of recharge }\end{array}$ \\
\hline & $\begin{array}{l}\text { Upland } \\
\text { ditch }\end{array}$ & $\begin{array}{l}\text { Man-made, trapezoidal } \\
\text { channel; deeper than } \\
\text { waterways, with less } \\
\text { vegetation on channel } \\
\text { bed; local depositional } \\
\text { bars present; channel is } \\
\text { semi-parallel to slope }\end{array}$ & $\begin{array}{l}\text { Minimal sediment } \\
\text { storage as bars on } \\
\text { channel bed }\end{array}$ & $\begin{array}{l}\text { Dominated by sediment } \\
\text { transport through low } \\
\text { gradient, but efficient } \\
\text { channels; } \\
\text { hydrologically } \\
\text { dominated by recharge }\end{array}$ \\
\hline & $\begin{array}{l}\text { Upland } \\
\text { channel }\end{array}$ & $\begin{array}{l}\text { Natural, single-thread } \\
\text { channel bound by } \\
\text { alluvium; channel may } \\
\text { locally be modified by } \\
\text { human activities }\end{array}$ & $\begin{array}{l}\text { Moderate storage } \\
\text { within channel as bars } \\
\text { and on floodplain }\end{array}$ & $\begin{array}{l}\text { Dominated by sediment } \\
\text { transport, but local } \\
\text { overbank deposition } \\
\text { occurs during floods; } \\
\text { channel may exhibit } \\
\text { both influent and } \\
\text { effluent conditions, } \\
\text { depending on season }\end{array}$ \\
\hline $\begin{array}{l}\text { Process } \\
\text { zones } \\
\text { within } \\
\text { bedrock } \\
\text { valleys }\end{array}$ & $\begin{array}{l}\text { Bedrock } \\
\text { channel }\end{array}$ & $\begin{array}{l}\text { Well-defined, often } \\
\text { rectangular channel } \\
\text { bound by bedrock; } \\
\text { locally, banks may } \\
\text { consist of alluvial } \\
\text { sediments; channel } \\
\text { gradients are relatively } \\
\text { steep }\end{array}$ & $\begin{array}{l}\text { Very little, if any, } \\
\text { sediment storage }\end{array}$ & $\begin{array}{l}\text { Dominated by bedrock } \\
\text { erosion and the } \\
\text { transport of sediment } \\
\text { delivered to the channel } \\
\text { from upstream reaches } \\
\text { and adjacent hillslopes }\end{array}$ \\
\hline \multirow[t]{5}{*}{$\begin{array}{l}\text { Process } \\
\text { zones } \\
\text { within } \\
\text { alluvial } \\
\text { valleys }\end{array}$} & $\begin{array}{l}\text { Axial } \\
\text { ditch }\end{array}$ & $\begin{array}{l}\text { Narrow, deep trapezoidal } \\
\text { channel excavated into } \\
\text { alluvial valley fill and } \\
\text { wetlands; often low } \\
\text { gradient }\end{array}$ & $\begin{array}{l}\text { Minimal sediment } \\
\text { storage }\end{array}$ & $\begin{array}{l}\text { Dominated by sediment } \\
\text { transport }\end{array}$ \\
\hline & $\begin{array}{l}\text { Alluvial } \\
\text { channel }\end{array}$ & $\begin{array}{l}\text { Natural, meandering } \\
\text { channel developed in } \\
\text { alluvial sediments along } \\
\text { relatively wide valleys }\end{array}$ & $\begin{array}{l}\text { Moderate quantities of } \\
\text { sediment are stored } \\
\text { within channel bars } \\
\text { and as overbank } \\
\text { deposits on floodplain }\end{array}$ & $\begin{array}{l}\text { Dominated by a } \\
\text { combination of } \\
\text { sediment transport and } \\
\text { deposition, depending } \\
\text { on flow conditions }\end{array}$ \\
\hline & $\begin{array}{l}\text { Alluvial } \\
\text { channel } \\
\text { with } \\
\text { wetlands }\end{array}$ & $\begin{array}{l}\text { Single thread, } \\
\text { meandering channel } \\
\text { developed in alluvial } \\
\text { sediment; found in wide } \\
\text { valleys with riparian } \\
\text { wetlands adjacent to } \\
\text { stream }\end{array}$ & $\begin{array}{l}\text { Significant sediment } \\
\text { storage as bars in } \\
\text { channel and overbank } \\
\text { deposits on floodplain } \\
\text { and within riparian } \\
\text { wetlands }\end{array}$ & $\begin{array}{l}\text { Dominated by sediment } \\
\text { deposition, although } \\
\text { some sediment is } \\
\text { transported through } \\
\text { channel; localized } \\
\text { zones of groundwater } \\
\text { discharge }\end{array}$ \\
\hline & Wetlands & $\begin{array}{l}\text { Wide, flat valley area } \\
\text { with water table at or near } \\
\text { the ground surface; } \\
\text { shallow channel(s) are } \\
\text { locally present }\end{array}$ & $\begin{array}{l}\text { High quantities of } \\
\text { sediment stored across } \\
\text { the wetland }\end{array}$ & $\begin{array}{l}\text { Dominated by sediment } \\
\text { deposition and } \\
\text { groundwater discharge }\end{array}$ \\
\hline & Reservoir & $\begin{array}{l}\text { Perennial bodies of open } \\
\text { water formed by } \\
\text { downstream dam }\end{array}$ & $\begin{array}{l}\text { Significant sites of } \\
\text { sediment storage }\end{array}$ & $\begin{array}{l}\text { Dominated by } \\
\text { deposition; fine } \\
\text { sediments may be } \\
\text { transported through } \\
\text { reach during high } \\
\text { flow events }\end{array}$ \\
\hline
\end{tabular}




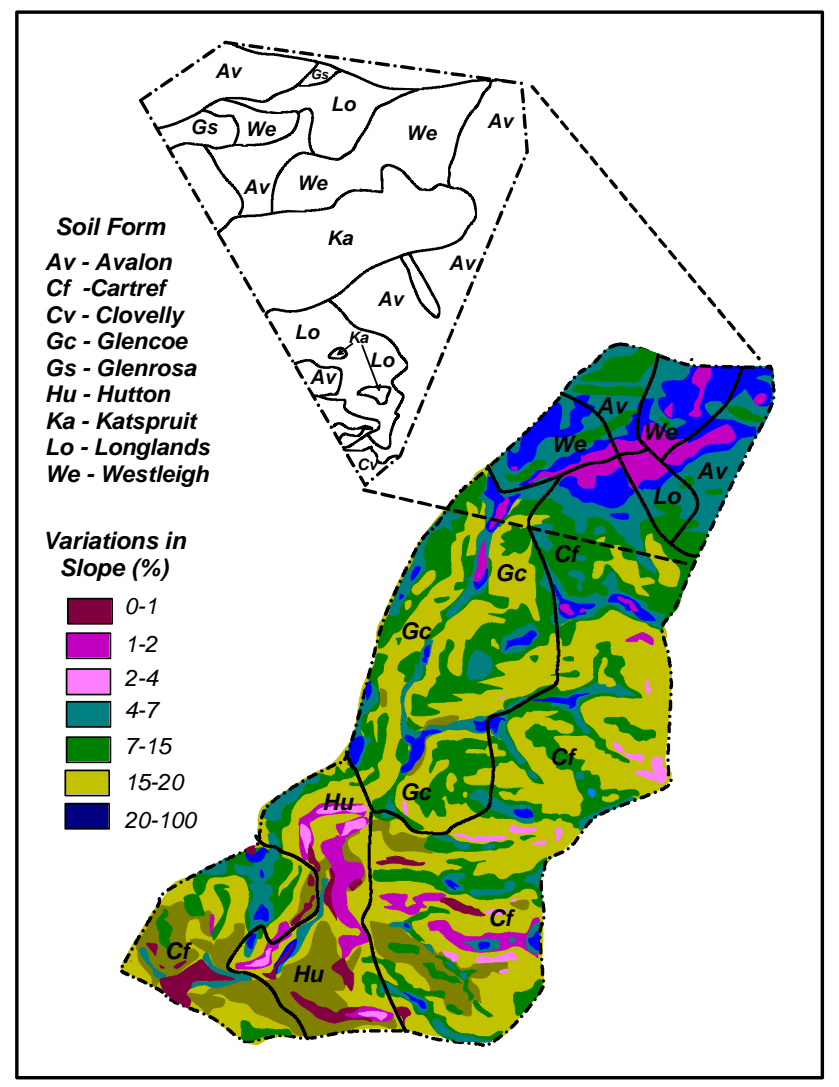

Fig. 3. Six soil types found on Mkabela Catchment (after Le Roux et al., 2006).

on the type and distribution of the process zones and the ability of the drainage network to transfer water, sediment, and any nutrients that they carry down catchment.

\subsection{Geochemical tracing}

Two types of geochemical tracing studies were applied to a series of sediment cores extracted from wetland and reservoir deposits within the Mkabela Catchment. First, a geochemical fingerprinting and mixing model approach was utilized to determine the relative percentage of sediment within a wetland of the upper subcatchment and an upstream section of the middle subcatchment that was derived from the primarily soil and land-use types within the basin. This analysis provides insights into the provenance of sediment delivered to depositional areas of the valley floor. Second, $\mathrm{Cu}$ and $\mathrm{Zn}$ were used as tracers to gain insights into the geomorphic connectivity, and changes in connectivity, with the entire drainage system through time. $\mathrm{Cu}$ and $\mathrm{Zn}$ could be utilized as tracers within the Mkabela Catchment because they are primarily associated with soil amendments used on vegetable (cabbage, maize) fields predominately located in headwater areas. Thus, variations in their concentration within sediment extracted from cores located along the drainage system

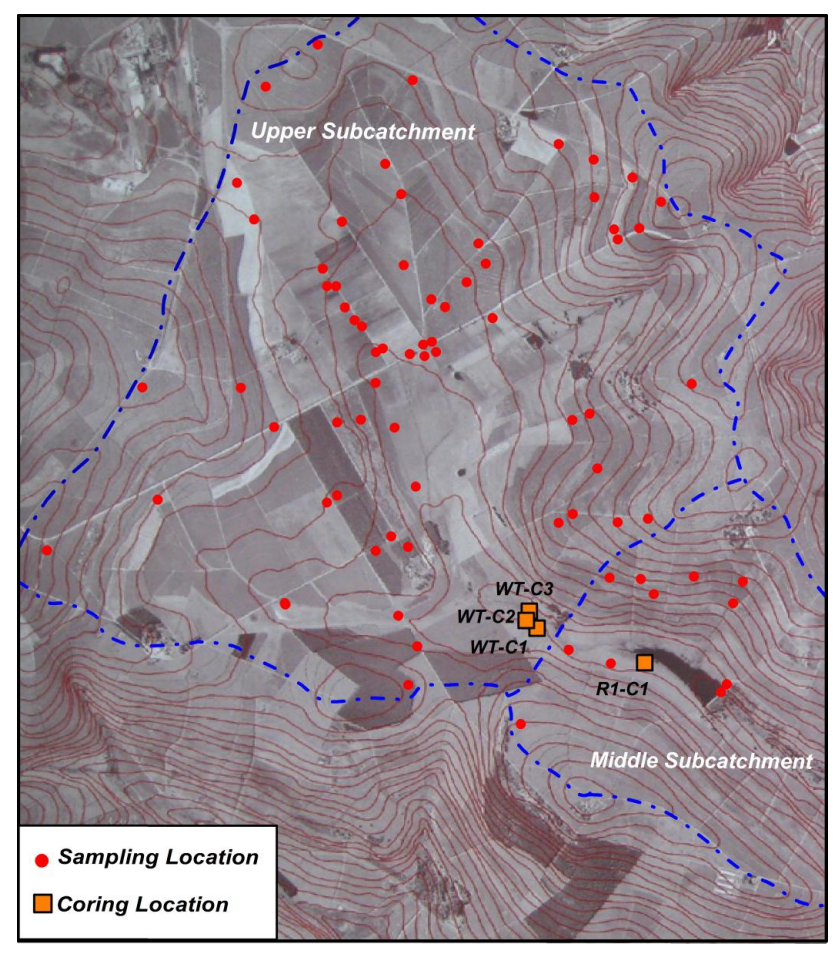

Fig. 4. Sampling and coring locations within the Mkabela Catchment.

reflected the downstream movement of particulates from the upper subcatchment, through the middle subcatchment, and ultimately to a riparian wetland cored within the lower subcatchment. When combined, results from the two methods yield insights into both sediment provenance from upland areas to the valley floor and the geomorphic connectivity of the drainage network over a period of decades.

\subsubsection{Collection, sedimentology and analysis of sediment cores}

The two geochemical tracing methods described above were applied to four cores collected in 2008 from the upper and middle subcatchments, including one core from the margin of the upstream-most reservoir (R1-C1), and three cores from the wetland (WT-C1, WT-C2, and WT-C3) (Fig. 4). A fifth core (B2WTC1) was collected in 2009 from a riparian wetland located along the channel in the uppermost portion of the lower catchment (Fig. 5). All of the cores were shipped to the Nevada Bureau of Mines and Geology and subsequently described, photographed, and sampled for geochemical analyses.

The samples were analyzed using a Micromass Platform ICP-HEX-MS for major elements (e.g., Si, $\mathrm{Al}, \mathrm{Fe}, \mathrm{Ca}, \mathrm{Mg}$, $\mathrm{Mn}, \mathrm{Na}, \mathrm{K}, \mathrm{Ti}$, and $\mathrm{P}$ ), total acid-soluble trace metals and metalloids (e.g., $\mathrm{Pb}, \mathrm{Zn}, \mathrm{Cd}, \mathrm{Cu}, \mathrm{Au}, \mathrm{Ag}, \mathrm{Se}, \mathrm{As}$ ), selected rare earth elements (e.g., $\mathrm{Ga}, \mathrm{Nb}, \mathrm{La}, \mathrm{Lu}, \mathrm{Hf}$ ), and selected isotopes (e.g., ${ }^{204} \mathrm{~Pb},{ }^{206} \mathrm{~Pb},{ }^{207} \mathrm{~Pb},{ }^{208} \mathrm{~Pb}$ ). Analysis involved 


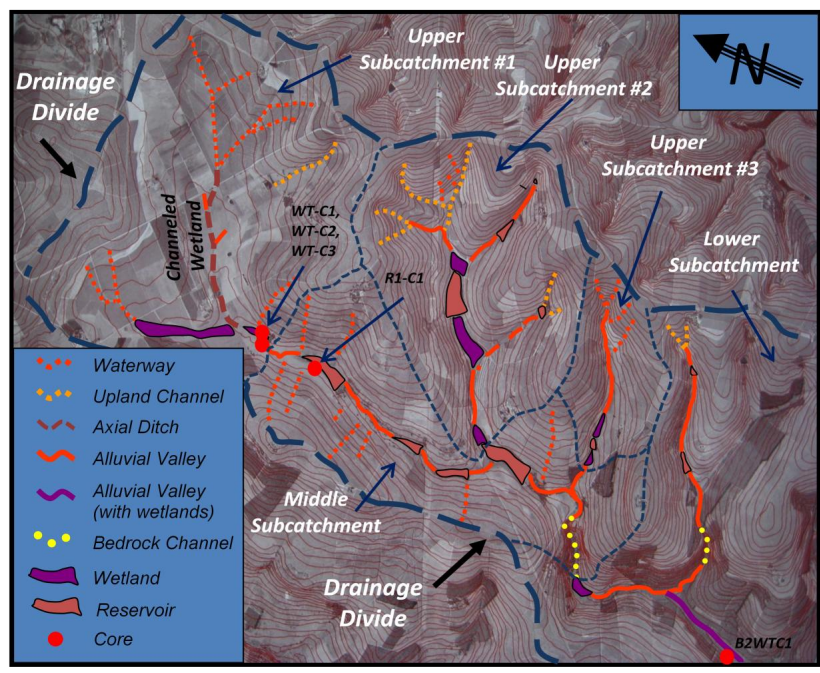

Fig. 5. Delineation of process zones and subcatchment areas within the upper and middle subcatchments.

the digestion of $200 \mathrm{mg}$ of dried and homogenized sediment, $<2 \mathrm{~mm}$ in size, in $125 \mathrm{~mL}$ polypropylene screw-top bottles containing $4 \mathrm{~mL}$ of aqua regia. These were sealed and held in a $100^{\circ} \mathrm{C}$ oven for $60 \mathrm{~min}$. The leachates were then transferred to $200 \mathrm{~mL}$ volumetric flasks, brought up to volume with ultra-pure water and stored until analyzed by ICP-MS. With respect to total elemental concentrations, the Platform was calibrated using USGS, NIST, and in-house standard reference materials (SRMs). Reagent blanks and the analyte concentrations for the SRMs were plotted against blanksubtracted integrated peak areas. A regression line was fitted to this array of calibration points and the equation of the line was used to quantify unknown sample concentrations. Deviation of standards from the regression line was used to estimate analytical accuracy, which was generally \pm 3 to $5 \%$ of the amount present when determining total concentrations. Replicate analyses were used to determine analytical precision, which was generally $< \pm 5 \%$ for most elements. With respect to $\mathrm{Pb}$ isotopic analyses, precision when comparing data from individual digestions was 0.2 to $0.3 \%$ relative deviation (one sigma) for ${ }^{206} \mathrm{~Pb},{ }^{207} \mathrm{~Pb}$, and ${ }^{208} \mathrm{~Pb}$. Instrumental precision was better. Accuracy of isotopic measurements was assessed with the NIST 981 lead isotope standard. Accuracy was typically better than $\pm 0.5 \%$, and systematic instrumental bias was corrected. Given the limited abundance of ${ }^{204} \mathrm{~Pb}$, precision and accurracy values were much higher; thus, ${ }^{204} \mathrm{~Pb}$ was not used as a potential tracer.

Selected cores were dated by means of ${ }^{210} \mathrm{~Pb}\left({ }^{137} \mathrm{Cs}\right.$ levels were too low to yield useful results). The analyses were carried out by Flett Research Ltd. located in Winnipeg, Canada. Flett Research was also contracted to use the raw ${ }^{210} \mathrm{~Pb}$ data to model the age-depth relationships within the cores. As is typical of ${ }^{210} \mathrm{~Pb}$ analyses, background values of ${ }^{210} \mathrm{~Pb}$ in the cores was determined by comparison with ${ }^{226} \mathrm{Ra}$
Table 2. Summary of samples collected in May 2008. Samples from roads were not included in the statistical analysis (see text).

\begin{tabular}{lrlr}
\hline $\begin{array}{l}\text { Land-use } \\
\text { category }\end{array}$ & \# Samples & Soil type & \# Samples \\
\hline Pasture & 10 & Avalon & 10 \\
Pine Forest & 2 & Cartref & 12 \\
Roads & 10 & Clovelly & 3 \\
Sugar Cane & 35 & Glencoe & 18 \\
Vegetables & 10 & Katspruit & 6 \\
Wattles & 6 & Longlands & 5 \\
& & Westleigh & 9 \\
\hline Total & 73 & Total & 63 \\
\hline
\end{tabular}

measured near the bottom of the core. The results were then used to determine sedimentation rates at the site. Depth-age curves were modeled using the constant rate of supply (CRS) method (Appleby and Oldfield, 1978).

\subsubsection{Upland sediment sampling and analysis}

Geochemical fingerprinting and mixing model analyses are used to assess the relative contribution of sediment from specific sediment sources to wetland and reservoir deposits located along the axial channel. In previous studies, sediment sources within a catchment have been defined in different ways (e.g., by land-use category, geological unit, or tributary basin) depending on the primary intent of the analysis. For this investigation, a total of 73 samples were collected from upland areas in May 2008 in order to characterize sediment sources (Fig. 4). The utilized sampling strategy was developed to allow the data to be stratified (categorized) in two different ways to determine the relative contribution of sediment from six land-use categories and seven soil types. The sampling scheme, then, allows an assessment of how both land use and soil type influence sediment production and availability (Table 2). The number of randomly collected samples in each land-use category roughly corresponds to the area that it covers within the catchment. All of the sampled soils were obtained from approximately the upper $2 \mathrm{~cm}$ of the ground surface and categorized according to land-cover and soil type, the latter by means of existing soils maps. The sediments therefore represent the material most likely to be eroded during a runoff event from shallow rills or interill areas. Erosion of sediment from hillslopes or valley deposits from gullies was not observed to be significant within the catchment, and the occurrence of unsupported ${ }^{210} \mathrm{~Pb}$ within a wetland core suggests that the majority of the sediment is derived from surface materials that have been subjected to the atmospheric deposition of ${ }^{210} \mathrm{~Pb}$. In order to reduce field variance in elemental concentrations, subsamples were collected from about 5 to 10 locations within a $5 \mathrm{~m}$ radius of the sampling site and composited to create a single sample. 
All of the upland samples were loaded into pre-cleaned polypropylene sampling containers, which were subsequently placed in plastic sampling bags, and shipped to the Nevada Bureau of Mines and Geology in the USA where they were analyzed by ICP-MS for the same elements as the core samples (as described above).

\subsubsection{Source modeling procedure}

Determination of the relative contribution of sediments from the source areas relies on the use of a sediment mixing model. The basic premise underlying the use of geochemical fingerprinting of NPS pollutants is that the processes involved in the erosion, transport, and deposition of sediment ultimately result in a deposit that represents a mixture of material derived from multiple source areas within the catchment. It is then possible to characterize the sediments within the source areas and the downstream alluvial/lacustrine deposits for a suite of parameters and statistically compare their parameter characteristics to unravel the relative proportion of sediment that was derived from each source type (Miller and Orbock Miller, 2007). During this investigation, the original model used by Miller et al. (2005) was modified using the approach provided by Rowen et al. (2000) to estimate sediment source contributions from the hillslopes to the cored deposits.

Constraints on the mixing model require that (1) each source type contributes some sediment to the mixture, and thus the proportions $\left(x_{j}, j=1,2, \ldots n\right)$, derived from $n$ individual source areas must be non-negative $\left(0 \leq x_{j} \leq 1\right)$, and (2) the contributions from all of the source areas must equal unity, i.e.,

$\sum_{j=1}^{n} x_{j}=1$

In addition, some differences (error) between the values of the $m$ measured parameters, in the source area, $a_{i j}(i=1 \ldots m$, $j=1 \ldots n)$ and the mixture, $b_{i}(i=1 \ldots m)$ must be allowed. The residual error corresponding to the $i$-th parameter can be determined as follows:

$\varepsilon_{i}=b_{i}-\sum_{j=1}^{n} a_{i j} x_{j}$

for $i=1,2, \ldots m$, where $a_{i j}(i=1,2,3 \ldots m, j=1,2, \ldots n)$ are the measurement on the corresponding $i$-th parameter within the $j$-th source area and $x_{j}$ is the proportion of the $j$-th source component in the sediment mixture. When the number of measured parameters is greater than the number of source areas $(m \geq n)$, the system of equations is overdetermined, and a "solution" is typically obtained using an iterative computational method that minimizes an objective function using a gradient search, thereby obtaining a best fit solution to the entire data set (Yu and Oldfield, 1989). There are several ways to obtain a best fit, but in previous studies, the objective function, $f$, has taken the form of the sum of the relative errors (Yu and Oldfield, 1989) where

$f\left(x_{1}, \ldots, x_{m}\right)=\sum_{i=1}^{m}\left|\varepsilon_{i} / b_{i}\right|$

or (Collins et al., 1997a)

$f\left(x_{1}, \ldots, x_{m}\right)=\sum_{i=1}^{m}\left(\varepsilon_{i} / b_{i}\right)^{2}$.

However, in the case where $f$ is relatively "flat", the gradient near zero may halt an iterative search method prematurely.

We take an alternative route, following Rowan et al. (2000) and Nash and Sutcliffe (1970), whereby we create the efficiency function

$E\left(x_{1}, \ldots, x_{m}\right)=1-\frac{\sum_{i=1}^{m}\left(\varepsilon_{i}\right)^{2}}{\sum_{i=1}^{m}\left(b_{i}-d_{i}\right)^{2}}$,

where $d_{i}(i=1,2,3 \ldots m)$ is the mean of the $i$-th parameter over all source regions. An ideal solution would result in $E=1$ or $100 \%$ efficiency. We then create a partition of all possible combinations of non-negative $n$-tuples $\left(x_{1}, \ldots, x_{n}\right)$ satisfying the unity constraint (Eq. 1), by increments of $\Delta x=0.05$. By evaluating $E$ at each of the $n$ tuples, we are able to determine the specific combination of the source contributions $\hat{x}=\left(x_{1}, \ldots, x_{n}\right)$ yielding the maximum efficiency on the partition.

As Rowan et al. (2000) pointed out, the efficiency function $\mathrm{E}$ has a maximum value at $\hat{x}$, but there may be a range of $n$-tuples having an efficiency within a specified tolerance of the maximum efficiency. That is, there are a number of solutions that are statistically equivalent. For example, using the data from sample WT-C1-1, the optimal efficiency value was 0.9963 when $50 \%$ of the contribution was from cane, $25 \%$ from Maize and vegetable, and $25 \%$ from wattle groves. Yet we see that there is a small range of proportions for each source that yields efficiency levels at the 0.95 level or above.

Attempts to model complex processes generally require simplifying assumptions, and the use of the sediment mixing model described above to assess sediment provenance is no exception. An important assumption inherent in the utilized approach is that it documents the ultimate source of sediment and not its proximal one. It is possible that sediment was eroded from a defined sediment source, transported downvalley and temporally deposited within the channel (or some other site) before being remobilized and transported to its current resting point where it was sampled. We believe that deposition and remobilization along the studied drainage system was minimal because the catchment areas upstream of the sampled sites are relatively small $(<1000 \mathrm{ha})$. The 
limited catchment areas increase the probability that eroded sand-sized and smaller sediment will be transported from the source to the point of deposition within the timeframe represented by a sample extracted from the analyzed cores.

It order for the model to describe the relative quantity of sediment eroded from each of the source areas, it must be assumed that the sediment leaves all sources and is transported downstream at an equal rate so that it arrives at the sampling point simultaneously. This assumption is often violated by differences in the proximity of a source to the sampled depositional area, or differences in the rate at which particles of differing size are transported downstream. It must be recognized, then, that the estimated contributions with regards to upland erosion rates are likely to be biased. We believe, however, that the bias is minimal because with the exception of the vegetable plots (which includes areas of maize), the defined sources upstream of the sampled wetland and reservoir are distributed throughout much of the catchment (Fig. 2). More importantly, the mixing model will accurately describe the source of the sediment delivered to, and found within, the wetland and reservoir deposits within the limitation of the utilized statistical methods. In this study, our interests primarily are focused on the relative contribution of sediment from the various source types found within the wetland and reservoir deposits (rather than the amount of sediment eroded from various source types) as these differences are reflective of downstream sediment delivery and connectivity.

\section{Results and discussion}

\subsection{Drainage network characteristics}

Field and cartographic data show that the drainage network within the Mkabela Basin can be subdivided into nine distinct process zones on the basis of their position on the landscape, valley dimensions and form, the underlying geological deposits in which they are developed, and the degree to which they have been affected by human activities (Lorentz et al., 2011). Each of these defined process zones is dominated by a suite of geomorphic and hydrologic processes as described in Table 1, and occurs with different frequencies within distinct segments of the catchment referred to as the upper, middle, and lower subcatchments (Fig. 5). The general size and relief of the subcatchments are provided in Table 3.

Upper subcatchments comprise the upstream-most (headwater) areas of both axial and large tributary drainage systems (Figs. 1 and 5). Within these upper subcatchments, hillslope drainage has often been significantly modified by cultivation, particularly in areas of sugar cane, in part to reduce the removal of sediment from the cultivated slopes. However, hillslopes are locally traversed by a relatively high density (approximately $2.5 \mathrm{~km} \mathrm{~km}^{-2}$ ) of man-made, low-gradient, $\mathrm{u}$ shaped "waterways" that are oriented perpendicular to topographic contours (Fig. 6a, Table 1). Hillslope runoff and flow

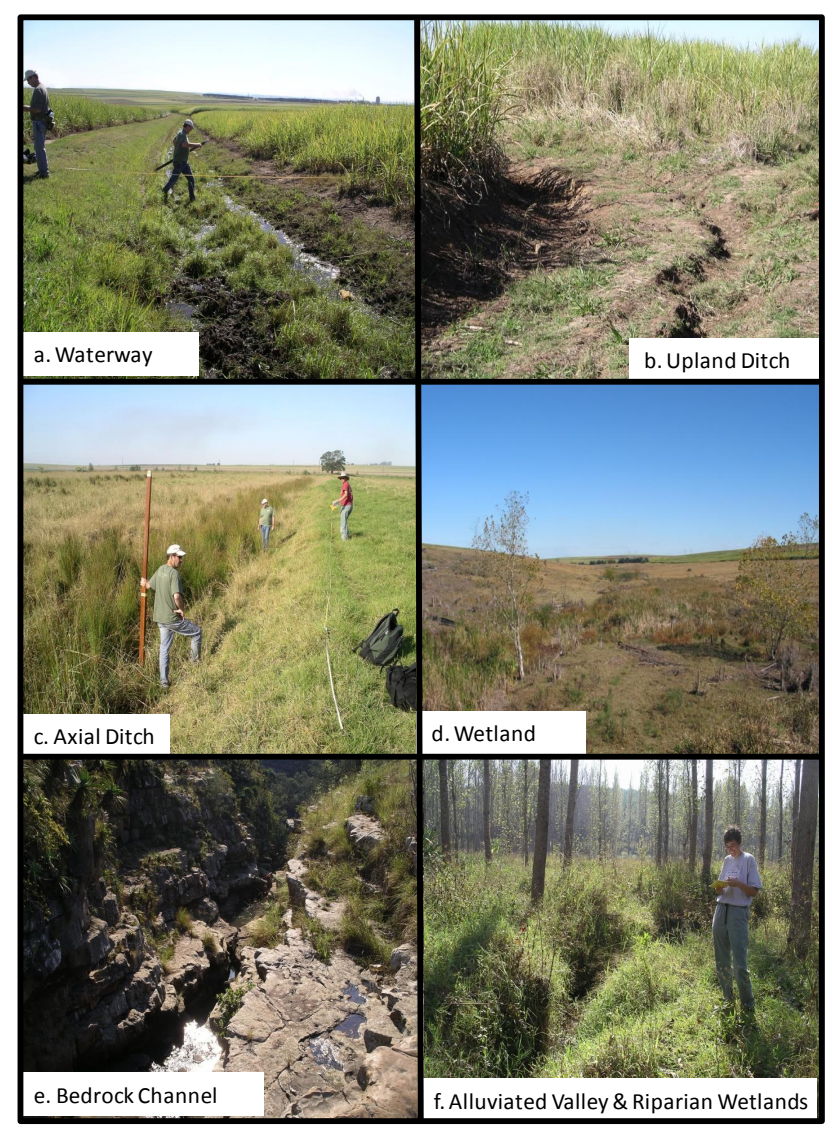

Fig. 6. Photographs of selected process zones types defined within the Mkabela Catchment.

along contoured features primarily deliver sediment to these waterways that is then feed into larger, incised channels, referred to as "upland ditches" (Figs. 5 and 6b). (Note that due to their small scale, lines of drainage parallel to contours were not considered here as a type of process zone.) The upland ditches represent heavily modified or relocated upland channels, or entirely man-made features. In either case, upland ditches are more incised and $\mathrm{v}$-shaped than the $\mathrm{u}$-shaped waterways. Further downstream, upland ditches and waterways deliver water and sediment to wetlands, or more frequently, an "axial ditch" (Figs. 5 and 6c). The largest axial ditch within the upper subcatchment was cut into unconsolidated valley fill deposits that comprise the axial valley. Until recently $(\sim 1990)$, this portion of the axial valley was dominated by a natural wetland devoid of a well-defined channel, but after the creation of the axial ditch upstream areas of the wetland were drained and converted to pasture (Fig. 5). Farther downstream, however, the axial ditch decreases dramatically in size and depth as it enters a less disturbed area of wetland formed upstream of a bedrock constriction in the valley floor (Fig. 5). This wetland defines the downstream limit of this upper subcatchment. The mouth of a tributary entering the axial valley from the north-west (Fig. 5) also exhibits 
Table 3. Summary of subcatchment characteristics. See Figs. 1 and 4 for subcatchment locations.

\begin{tabular}{lrr}
\hline Subcatchment & $\begin{array}{r}\text { Area } \\
\text { (ha) }\end{array}$ & $\begin{array}{r}\text { Relief } \\
(\mathrm{m})\end{array}$ \\
\hline $\begin{array}{l}\text { Upper subcatchment 1 } \\
\text { (headwaters) }\end{array}$ & 1300 & 80 \\
$\begin{array}{l}\text { Upper subcatchment 2 } \\
\text { Upper subcatchment 3 }\end{array}$ & 720 & 150 \\
$\begin{array}{l}\text { Middle subcatchment } \\
\text { Lower subcatchment } \\
\text { (upstream of coring }\end{array}$ & 700 & 90 \\
$\begin{array}{l}\text { site) } \\
\text { Lower subcatchment } \\
\text { (total area) }\end{array}$ & 19700 & 175 \\
\hline
\end{tabular}

an extensive wetland devoid of an integrated network of surface channels. Field observations indicate that the water table within the wetland is below the ground surface during the dry season, but is at or near the ground surface during wetter months. The extensive wetlands found within the axial valley system of the upper catchment are dominated by relatively low channel and valley gradients and depositional processes.

The middle subcatchment begins downstream of the bedrock constricted wetland (Fig. 5). Hillslopes within this portion of the basin are also dominated by sugar cane fields that possess numerous waterways (Fig. 2). However, many of the waterways along the western side of the catchment are short, drain relatively small areas, and are disconnected geomorphically from the axial valley, limiting their ability to directly deliver sediment to the axial channel. Perhaps of more importance with respect to sediment transport, the axial drainage system within the middle subcatchment is characterized by a continuous, relatively shallow, but high gradient $\left(\sim 0.008 \mathrm{~m} \mathrm{~m}^{-1}\right)$ alluvial channel that is locally boarded by disturbed riparian wetlands. The channel is disrupted by four separate farm dams and their associated reservoirs (Fig. 5). Water flows over the top of the dams throughout most of the year, but during wet season storms the movement of water through the reservoir and over the dam can be particularly intense. Immediately below the fourth dam, the stream consists of a bedrock channel locally characterized by a series of knickpoints (Fig. 6e). The river then enters the lower subcatchment.

The lower subcatchment is dominated by a low gradient, alluvial channel boarded by extensive and forested riparian wetlands (Figs. 2 and 6f). The wetlands are intermingled with areas of sugar cane that also occur locally on hillslopes. In marked contrast to the upstream subcatchments, upland areas within the lower subcatchment exhibit very few waterways, axial ditches, or upland channels, in spite of the fact that valley floors are incised well below the surrounding terrain. The
Table 4. Discriminate analysis classification matrix. (A) Soil type and (B) land use.

\begin{tabular}{lcccccccc}
\hline \multirow{2}{*}{ (A) } & \multicolumn{7}{c}{ Number of samples classified per soil type } & \multirow{2}{*}{$\%$} \\
\cline { 2 - 6 } Soil type & Av & Cf & Cv & Ka & Gc & Lo & We & Correct \\
\hline Av & 9 & 0 & 0 & 1 & 0 & 0 & 0 & 90 \\
Cf & 0 & 9 & 3 & 0 & 0 & 0 & 0 & 75 \\
Cv & 0 & 0 & 3 & 0 & 0 & 0 & 0 & 100 \\
Ka & 0 & 0 & 1 & 5 & 0 & 0 & 0 & 83 \\
Gc & 3 & 0 & 1 & 0 & 11 & 1 & 2 & 61 \\
Lo & 0 & 0 & 0 & 0 & 0 & 5 & 0 & 100 \\
We & 0 & 0 & 0 & 0 & 1 & 0 & 8 & 89 \\
Totals & 12 & 9 & 8 & 6 & 12 & 6 & 10 & 79 \\
\hline (B) & & Number of samples classified per soil type & $\%$ \\
Land use & Sc & Veg & Wt & Pine & Rds & Past & Correct & \\
\hline Sc & 22 & 3 & 9 & 0 & 1 & 0 & 63 & \\
Veg & 0 & 8 & 2 & 0 & 0 & 0 & 80 & \\
Wt & 0 & 0 & 5 & 1 & 0 & 0 & 83 & \\
Pine & 1 & 0 & 0 & 1 & 0 & 0 & 50 & \\
Rds & 0 & 0 & 2 & 0 & 6 & 2 & 60 & \\
Past & 0 & 0 & 2 & 0 & 1 & 7 & 70 & \\
Totals & 23 & 11 & 20 & 2 & 8 & 9 & 67 & \\
\hline
\end{tabular}

Av - Avalon; Cf - Cartfer; Cv - Clovelly; Ka - Katspruit; Gc - Glencoe; Lo Longlands; We - Westleigh; Sc - Sugar Cane; Veg. - Vegetables; Wt - Wattles; Pine - Pine Grove; Rds - Roads; Past - Pasture

low gradient nature of the axial channel, and the broad alluvial valley consisting of extensive riparian wetlands, forms a highly depositional environment that allows for the storage of large volumes of sediment (as described below).

\subsection{Sediment provenance analyses}

\subsubsection{Delineation of geochemical fingerprints}

The use of geochemical fingerprinting methods to elucidate sediment provenance from non-point sources has increased significantly during the past two decades (Slattery et al., 1995; Collins, 1995; Collins et al., 1997a,b, 1998; Walling et al., 1999; Bottrill et al., 2000; Russell et al., 2001; Douglas et al., 2003, 2005, 2010; Miller et al., 2005; Foster et al., 2007, 2012). Geochemical fingerprinting methods were used here to determine the predominant source of sediments found in three wetland and one reservoir sediment cores collected from along the drainage network. Two separate analyses were carried out, one in which sediment sources were defined on the basis of land use (Fig. 2), and the other for which sources were defined on the basis of soil type (Fig. 3).

With respect to the soil type, eight elements were identified as fingerprints, including $\mathrm{Ti}, \mathrm{Cr}, \mathrm{Ga}, \mathrm{Nb}, \mathrm{La}, \mathrm{Ce}, \mathrm{Lu}$, and $\mathrm{Hf}$ using a discriminant function analysis as described in the methods section. All of these elements are known to be highly immobile in freshwater systems with normal Eh and $\mathrm{pH}$ conditions. The discriminant function correctly classified $79 \%$ of the samples (Table $4 a$ ). The most incorrectly classified samples were obtained from Cartref and Glencoe soils, possibly because both are found in similar locations 

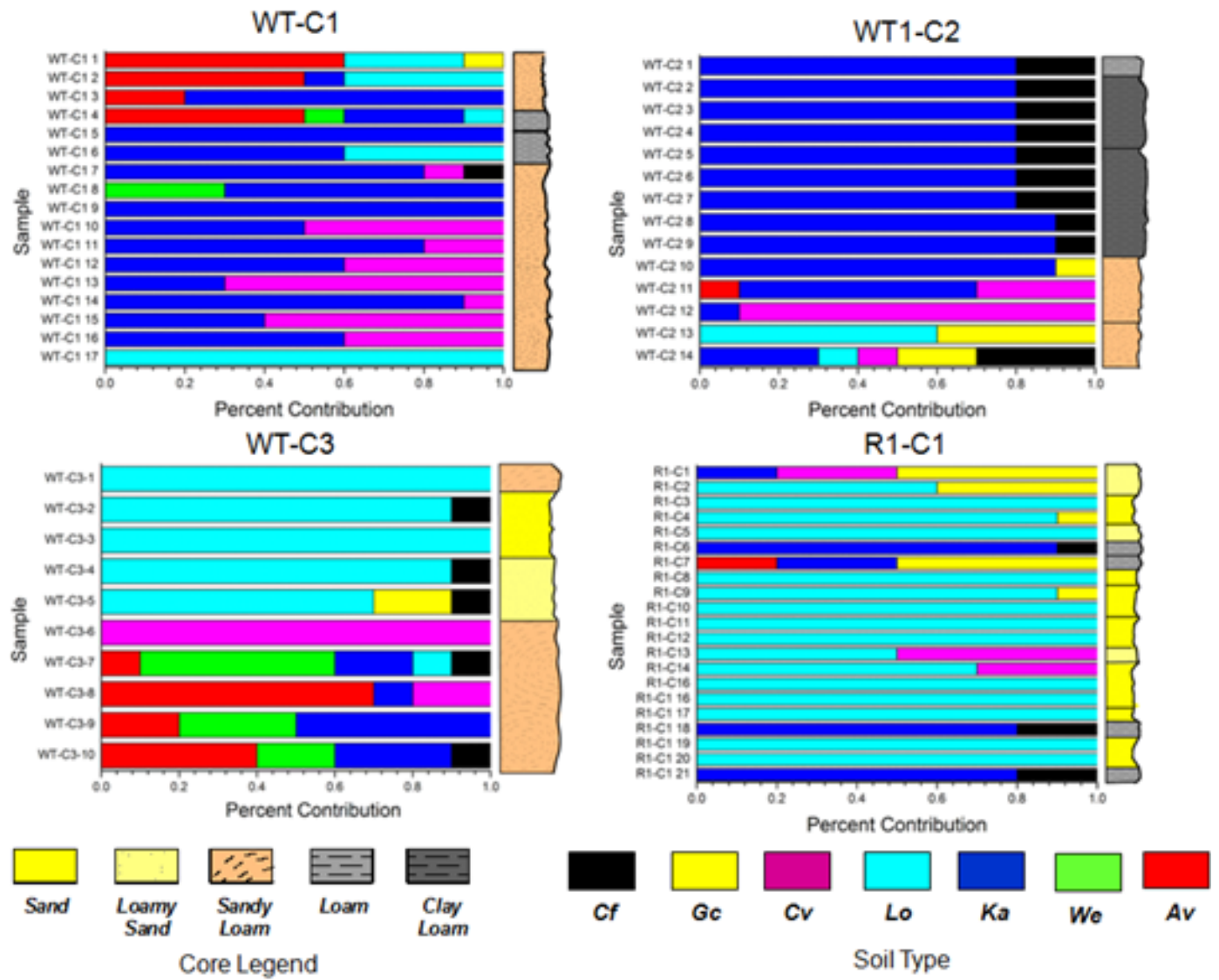

Fig. 7. Relative percent of sediment derived from specific soil types within the catchment. Av - Avalon, Cf - Cartref, Cv - Clovelly, Gc Glencoe, Ka - Katspruit, Lo - Longlands, We - Westleigh.

on the landscape (steep slopes) and possess sandy-textured horizons.

A stepwise discriminate analysis was also carried out for sediment sources defined by land use. The selected parameters were the same as those used to differentiate soil types ( Ti, Cr, Ga, Nb, La, Ce, Lu, and Hf) (Table 4b). Source material samples collected from specific land-use categories were incorrectly classified about a third of the time. The difficulty of correctly identifying a particular land cover may be related to two factors. First, crop rotations may potentially produce a mixed geochemical signal with regards to land use. The mapping of sediment provenance onto land use when land use has changed through time is a recognized problem associated with the use of geochemical fingerprinting techniques. Primarily at issue is whether alterations in land use will lead to changes in the concentration of the elements used to define the geochemical fingerprint such that the geochemistry of the sediment source samples reflects both its current and past land-cover history, or, perhaps more accurately, inhibits the identification of a geochemical fingerprint capable of defining a specific land-use type. While potentially problematic, we believe that shifting land use did not significantly affect our results. Land areas covered in wattle and pine forests as well as pasture have presumably changed little over at least the past four decades. Areas planted in sugar cane also have been relatively stable since its introduction into the catchment in 1968. Most maize fields were present prior to 1968 , although some areas of maize were converted to sugar cane as it was introduced into the catchment. The most recent transition in land use is associated with the conversion of a dairy operation in the headwaters of the catchment to cabbage fields around 2001. Difficulties in creating a fingerprint as a result of these land-use alterations that occurred are most likely to be associated with elements applied to agricultural fields as a soil amendment (e.g., fertilizers). The geochemical fingerprints developed for the various land-use types defined in this study were based on highly immobile rare earth elements which are less likely of exhibiting rapid changes in concentration within the sampled materials.

The second potential cause for the observed misclassification of land-use type is that a given land-use category may be underlain by several soil types, complicating its geochemical signature. In fact, when soil type is added to the discriminate analysis as a numeric value the ability to correctly classify land cover increases significantly (to $86 \%$ ). 

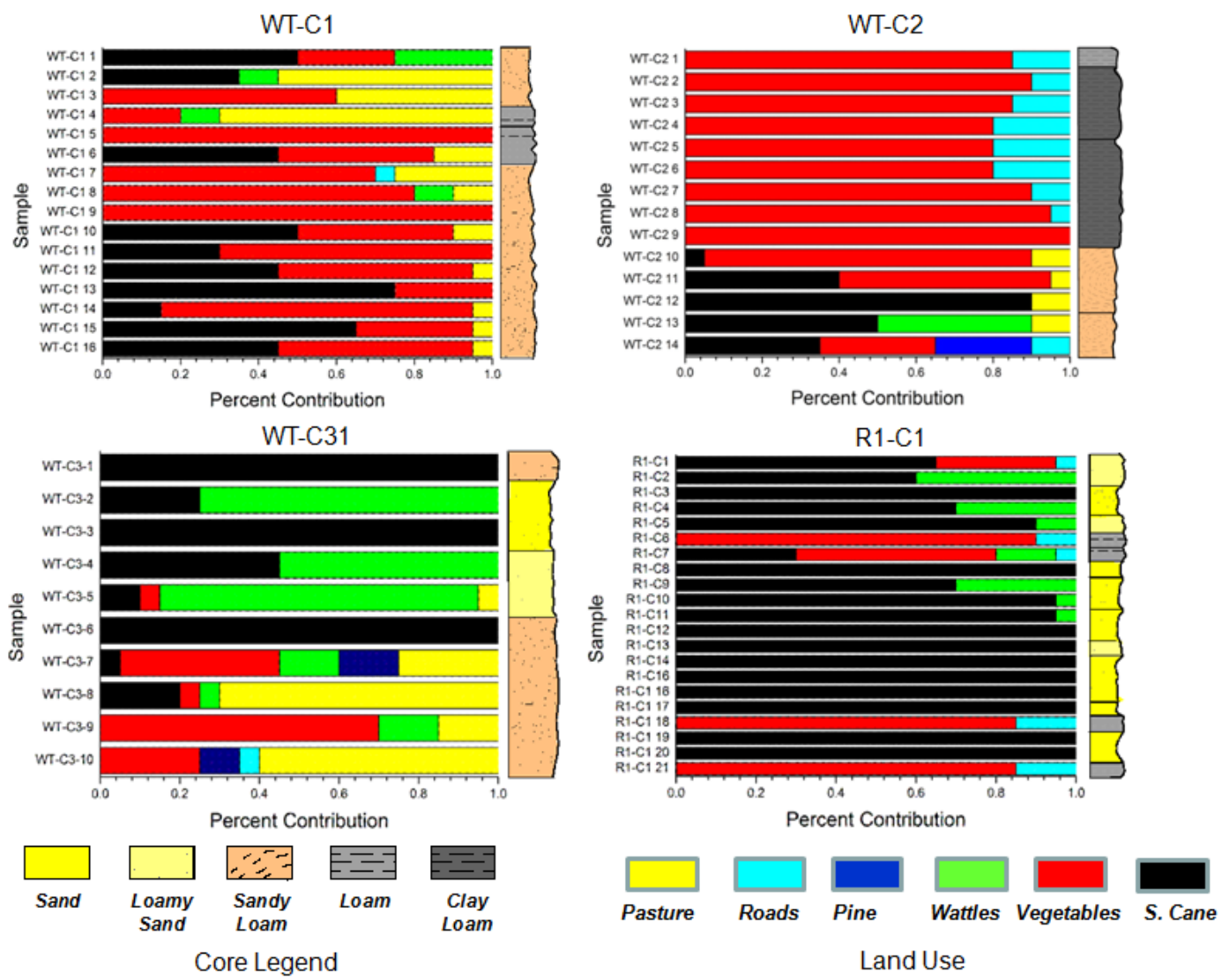

Fig. 8. Relative percent of sediment derived from specific land-use types within the catchment.

\subsubsection{Modeling results}

The location and general characteristics of cores collected, geochemically analyzed, and modeled to assess sediment provenance within the Mkabela Basin are provided in Fig. 5 and Table 5, respectively. The soil source modeling (in which provenance was defined on the basis of soil type) shows that three distinct intervals are present in WT1-C1 (Fig. 7). Samples 10-16 are composed exclusively of Clovelly (CV) and Katspruit (Ka) soil types. The relative contributions of Clovelly range from 10 to $70 \%$, and average $40 \%$; Katspruit ranges from 40 to $90 \%$.

Samples 7-9 are dominated by Katspruit (>60\%), with minor contributions of Westleigh (We), Avalon (Av), Catref (Cf), and Longlands (Lo), in three of the samples. The upper part of the core (samples 1-4) primarily consist of Avalon (30-60\%), Katspruit (10-70\%), and Longlands (10-40\%) soil types, with minor contributions of Glencoe $(\mathrm{Gc})$ and Westleigh.

Boundaries between two of the major source type intervals within the core roughly correspond to stratigraphic unit boundaries. The boundary between the mid-interval (samples 7-9) and the lower interval (samples 10-16) imprecisely correlate with a gradational stratigraphic boundary within the core.
Core WT-C1 can also be subdivided into three distinct intervals with respect to modeled land-use sediment sources (Fig. 8). The three intervals correlate with the intervals denoted for soil type. Samples 10-16 are composed predominantly of sediment from cane $(15-75 \%)$ and vegetable (30-80\%) fields. The samples also contain minor amounts of sediment from pastures $(<10 \%)$. The intermediate interval (samples 7-9) is dominated by sediment from vegetable fields (generally $>70 \%$ ). However, in comparison to the lower unit, the interval exhibits a notable increase in sediment from pastures $(\sim 10-25 \%)$, and localized, minor amounts of material from roads and wattle-covered terrain. With the exception of sample 5, the upper 6 samples contain a wider range of source inputs. The dominant sources for these samples include sediment from vegetable fields, pastures, and cane fields, with lesser amounts of sediment from wattle-covered terrain (Fig. 8).

Core WT-C2 (also from the upper catchment wetland) can be subdivided into three intervals on the basis of sediment provenance with respect to soil types (Fig. 7). The lowermost interval including samples 13-14 consists of a medium sandy loam, and possesses sediment from a variety of soil types including Longlands (10-60\%), Glencoe (20-40 \%), Cartref $(0-30 \%)$, Katspruit $(0-30 \%)$, and Clovelly $(0-10 \%)$. This lowermost interval is overlain by a $16 \mathrm{~cm}$ unit ranging from 
Table 5. Summary of collected cores.

\begin{tabular}{|c|c|c|}
\hline Core & Location & Characteristics \\
\hline Core WT-C1 & $\begin{array}{l}\text { Located within an extensive wetland } \\
\text { approximately } 40 \mathrm{~m} \text { from its } \\
\text { downstream terminus. The area is } \\
\text { dominated by a relatively flat } \\
\text { surface about } 1 \mathrm{~m} \text { above a small } \\
\text { channel that traverses the wetland. } \\
\text { At the time of coring, the water } \\
\text { table was about } 20 \mathrm{~cm} \text { below the } \\
\text { surface, but based on the vegetation, } \\
\text { periodically rises to ground level. }\end{array}$ & $\begin{array}{l}\text { Total length is } 122 \mathrm{~cm} \text {. Stratigraphic relationships, } \\
\text { including the presents of a buried paleosol consisting of } \\
\text { a light brown, very sticky, gravelly clay loam, suggests } \\
\text { that historic sediment is } 107 \mathrm{~cm} \text { thick. A total of } 16 \\
\text { samples, collected at } 7 \mathrm{~cm} \text { increments were obtained } \\
\text { from historic deposits. No sample was collected across } \\
\text { a stratigraphic unit boundary }\end{array}$ \\
\hline Core WT-C2 & $\begin{array}{l}\text { Obtained from a flat surface about } 1 \mathrm{~m} \\
\text { above the wetland channel, about } \\
250 \mathrm{~m} \text { upstream of the wetland's } \\
\text { downstream terminus. The location } \\
\text { was located about } 15 \mathrm{~m} \text { from the } \\
\text { channel edge. The water table was } \\
\text { about } 20 \mathrm{~cm} \text { below the surface at } \\
\text { the time of coring. }\end{array}$ & $\begin{array}{l}\text { Total length is } 112.5 \mathrm{~cm} \text {. Sediments below } 90 \mathrm{~cm} \text { in } \\
\text { depth have been interpreted to pre-date historic } \\
\text { deposition; they are heavily weathered, and exhibit } \\
\text { significant accumulations of clay. A total of } 16 \text { samples } \\
\text { were collected at } 7 \mathrm{~cm} \text { increments. As was the case for } \\
\text { the other cores, samples did not cross stratigraphic } \\
\text { boundaries. }\end{array}$ \\
\hline Core WT-C3 & $\begin{array}{l}\text { Obtained from a flat surface about } 1 \mathrm{~m} \\
\text { above the wetland channel, about } \\
250 \mathrm{~m} \text { upstream of the wetland's } \\
\text { downstream terminus. }\end{array}$ & $\begin{array}{l}\text { Total length is } 130 \mathrm{~cm} \text {. The upper } 69.5 \mathrm{~cm} \text { of sediment } \\
\text { is thought to be of historic age based on stratigraphic and } \\
\text { geochemical data. A total of } 10 \text { samples were collected } \\
\text { from historic sediments at } 7 \mathrm{~cm} \text { increments. None of the } \\
\text { samples cross stratigraphic boundaries. }\end{array}$ \\
\hline Core R1-C1 & $\begin{array}{l}\text { Collected from the edge of the first } \\
\text { reservoir along the main drainage in } \\
\text { a low-lying area that is inundated } \\
\text { during flood events. }\end{array}$ & $\begin{array}{l}\text { Total length is } 140 \mathrm{~cm} \text {. The core was sampled at } 7 \mathrm{~cm} \\
\text { increments for }{ }^{210} \mathrm{~Pb} \text { dating, generating a total of } \\
20 \text { samples. A total of } 21 \text { samples were collected for } \\
\text { geochemical analyses. Two samples of similar thickness } \\
\text { were collected for units more than } 5 \mathrm{~cm} \text { thick. All of the } \\
\text { sediment appears to be of historic age. }\end{array}$ \\
\hline BW2TC1 & $\begin{array}{l}\text { Riparian wetland within lower } \\
\text { catchment }\end{array}$ & $\begin{array}{l}\text { Total length is } 179 \mathrm{~cm} \text {. All sediment appears to be of } \\
\text { historic age. A total of } 21 \text { samples were collected at } \\
8 \mathrm{~cm} \text { intervals. }\end{array}$ \\
\hline
\end{tabular}

sample 11 to 12 that is dominated by sediment from Clovelly (30-90\%) and Katspruit (10-60\%) soils, with minor contributions from Avalon soils (0-10\%). The majority of the core, ranging from sample 1 to 11 , is dominated by sediment from Katspruit (80-90\%), with $<20 \%$ coming from Catref soils, except in the lowermost sample. This latter sample contains sediment from Glencoe rather than Catref soils. Changes in sediment source contributions correspond to stratigraphic unit boundaries.

With regards to land use, sediment provenance within Core WT-C2 can be subdivided into two intervals which closely, but not precisely, match the boundaries denoted for soils. The lowermost deposits (sample 10) contain relatively large percentages of sediment from cane fields (Fig. 8), whereas the overlying sediments are predominantly derived from vegetable fields ( $>80 \%$ ) with lesser contributions from roads. Sample 10, located along the boundary between the two intervals appears transitional in terms of source, consisting of large amounts of sediment from vegetable fields (as is the case for the overlying deposits), as well as minor amounts of sediment from cane fields and pastures (as is the case for the lower deposits).

The sediments in Core WT-C3 (from the upper catchment wetland) can be subdivided into two predominate intervals in terms of the soil types from which the sediments were derived (Fig. 7). The lowermost sediments (samples 7-10) are composed primarily of Avalon, Westleigh, and Katspruit soils, with minor amounts (10\%) of Catref and Longlands in sample 7. The uppermost part of the core (samples 1-5) consists primarily of sediment from Longlands soils, with lesser ( $\sim 10 \%$ ) from Catref soils. Sample 6 , which separates the two intervals and which is found at the top of a stratigraphic unit, is highly anomalous, consisting exclusively of sediment from Clovelly soils. 
Changes in sediment provenance modeled with respect to land use closely parallel noted changes in provenance assessed by soil type. The lowermost sediments (samples 7$10)$ are composed primarily of sediment from pastures (15$70 \%)$, and in decreasing order, vegetable fields (5-70\%), wattles groves $(5-15 \%)$, pine groves $(0-15 \%)$, cane $(5-$ $20 \%)$ and roads $(0-10 \%)$. The uppermost part of the core (from 0-30 cm, samples 1-5) consists primarily of sediment from cane fields $(10-100 \%)$ and wattles $(45-85 \%)$, with small amounts $(5 \%)$ from vegetable fields and pastures in sample 5. Sample 6, which separates the two intervals and which is found at the top of a stratigraphic unit, consists exclusively of sediment from cane fields.

Core R1-C1 was obtained from the margin of reservoir located within the middle catchment. The majority of sediment within the reservoir was derived from Longlands soil, with the exception of five notable, but thin, horizons. Sampling intervals 18 and 21 at the bottom of the core are composed predominantly of sediment from Katspruit type soils. Samples 13-14 contains 30-50\% Covelly soil material, in addition to Longlands. The loamy fine sand to loam textured materials associated with samples 6 and 7 contain no definable sediment from Longlands soils, but are dominated by Katspruit (sample 6) or a mixture of Katspruit, Glencoe, and Clovelly (sampling interval 7). The uppermost sediments also contain significant amounts of Clovelly type materials as well as Glencoe and Katspruit in the case of sampling interval 1.

With regards to land use, the majority of the sand dominated sediment within Core R1-C1 appears to have been derived from cane fields. Fine-grained, loamy sediments (e.g., found in sampling intervals $1,6,7,18$, and 19) appear to have been derived primarily from vegetable plots. Figure 8 also shows that there is a notable increase in the contribution of sediment from wattle groves within and above sample 11, as well as vegetables and roads, at and above sample 8 following a period of input primarily from cane fields between samples 12 and 16.

\subsubsection{Sedimentation rates}

Samples from two cores (WT-C1 and R1-C1) were analyzed for ${ }^{210} \mathrm{~Pb}$ to (1) determine the age of the deposits as a function of depth, and (2) estimate sedimentation rates for specific time intervals. These two cores were selected on the basis of their location (one from the upstream-most wetland and one from the reservoir) and their relatively complete stratigraphic nature (in which the core extended through historic to pre-historic sediments). ${ }^{210} \mathrm{~Pb}$ in the relatively fine-grained sediment of Core WT-C1 was measurable, but low (Fig. 9). A ${ }^{226} \mathrm{Ra}$ measurement of $0.82 \mathrm{DPM} \mathrm{g}^{-1}$ in the deepest section (at $112-122 \mathrm{~cm}$ depth), which based on stratigraphic data represent pre-historic sediment, is similar to the ${ }^{210} \mathrm{~Pb}$ measurement of $0.60 \mathrm{DPM} \mathrm{g}^{-1}$ in the same section. This ${ }^{210} \mathrm{~Pb}$ measurement suggests that background levels of ${ }^{210} \mathrm{~Pb}$

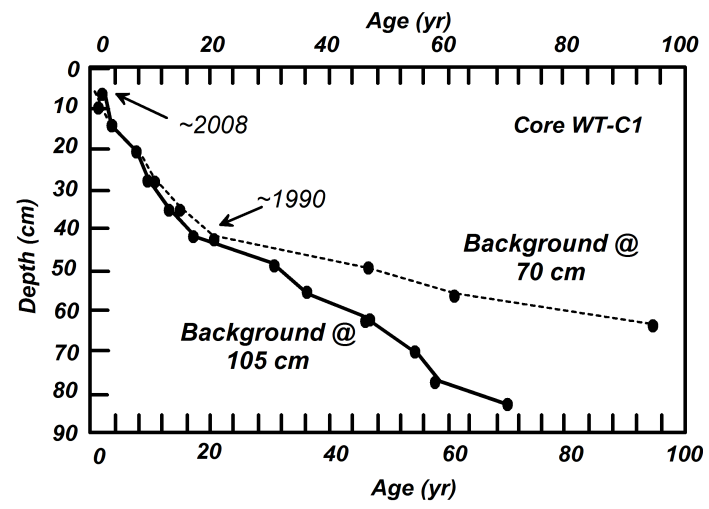

Fig. 9. Estimated age of the sediments in Core WT-C1 as determined by ${ }^{210} \mathrm{~Pb}$ analysis. The slope of the line in age-depth plot represents the sedimentation rate. Sedimentation rates increase above $41.2 \mathrm{~cm}$, or after about 1992.

have been attained at $105 \mathrm{~cm}$. Although ${ }^{210} \mathrm{~Pb}$ values diverge slightly from the measured ${ }^{226} \mathrm{Ra}$ value, background may have been attained at the shallower depth of $70 \mathrm{~cm}$ depth (R. Flett, personal communication, 2008).

Age-depth relations were modeled using the constant rate of supply (CRS) method for background values at both 105 and $70 \mathrm{~cm}$, generating two age-depth curves (Fig. 9). Both curves are presented to provide the range of age-depth relations that may exist, depending on the background depth that is utilized. The two analyses yield similar results for the upper 6 samples (last $20 \mathrm{yr}$ ), but progressively diverge after that (Fig. 9). Both analyses indicate that sedimentation rates within the wetland are relatively uniform until the end of the 1980 s, at which point sedimentation rates begin to increase significantly to the present.

The ${ }^{210} \mathrm{~Pb}$ content of the sediment from R1-C1 was very low and irregular, showing no consistent pattern. This pattern is presumably related to the coarse-grained nature of the reservoir deposits as measurable concentrations were found in the fine-grained units. In any case, it was not possible to determine with confidence the date of deposition of any of the sediments within the core from the reservoir (R1-C1).

\subsubsection{Controls on sediment source}

An examination of the core data collected from the wetland and reservoir shows that the deposits exhibit significant spatial (depth, areal) variations in grain size. These variations between subcatchment areas are dramatic. The most upstream reservoir within the catchment (located in the upper middle subcatchment) is dominated by sand, as was mentioned earlier (Figs. 7 and 8). The wetland, however (located in the upper subcatchment, upstream of the reservoirs) consists primarily of loamy or sandy loam deposits. The observed variations in deposit grain size presumably reflect changes in sediment source and the nature of the source materials, hydraulic sorting of the sediment during transport and 
Table 6. Brief description of the primarily soil types found in the study area (after Le Roux et al., 2006).

\begin{tabular}{ll}
\hline Soil type & General characteristics \\
\hline Avalon (Av) & $\begin{array}{l}\text { The Avalon soil type surveyed to } 120 \mathrm{~cm} \text { depth and consists } \\
\text { primarily of soft plinthic B horizons which is a sandy yellow-brown } \\
\text { B horizon underlain by hard plinthic horizons. }\end{array}$ \\
\hline Cartref (Cf) & $\begin{array}{l}\text { Shallow, sandy soils with very little water holding capacity found on } \\
\text { steep, short, convex hillslopes. }\end{array}$ \\
\hline Clovelly (Cv) & Associated with, and similar to, Longlands soil type. \\
\hline Glencoe (Gc) & $\begin{array}{l}\text { Similar to Avalon soil type, but dominated by hard plinthic } \\
\text { subhorizon; found on steeper slopes of higher relief. Parent material } \\
\text { is thought to be the Natal Group Sandstone (NGS). }\end{array}$ \\
\hline Hutton (Hu) & $\begin{array}{l}\text { Found near crest and midslopes of high relief, steep hillslopes. } \\
\text { Moderately drained, underlain by NGS. }\end{array}$ \\
\hline Katspruit (Ka) & $\begin{array}{l}\text { Clayey, strongly gleyed soils found on low-relief (10-15 m) terrain, } \\
\text { particular valley bottoms. }\end{array}$ \\
\hline Longlands (Lo) & $\begin{array}{l}\text { The Longlands soil type was surveyed up to 120 cm depth and } \\
\text { consists of soils that are sandier than the Avalon soils with similar } \\
\text { profile of soft plinthic B horizons well developed underlain by hard } \\
\text { plinthic horizons. }\end{array}$ \\
\hline Westleigh (We) & $\begin{array}{l}\text { The Westleigh soil type was surveyed up to 110 cm depth and } \\
\text { consist a poorly drained hydrosequence dominated by clayey soils } \\
\text { with prominent mottling and deep, clayed subsoils. }\end{array}$ \\
\hline
\end{tabular}

deposition, differences in flow magnitudes (owning to differences in catchment size), or a combination of the three factors.

The utilized sediment mixing model suggests that nearly all of the sand-sized sediment within the reservoir is derived from Longlands and, to a much lesser degree, Clovelly soils. Both of these soil types exhibit sandy textures within the catchment (Table 6; Le Roux et al., 2006). They tend to be sandier than the clay-rich Westleigh or Avalon hillslope soils, and much sandier than valley bottom soils such as the clayey Katspruit soil (Le Roux et al., 2006). The geographic distribution of Longlands and Clovelly soils has been mapped in detail for only the headwaters of the Mkabela Catchment (Fig. 3). Here Longlands and Clovelly soils are located along the eastern corner of the catchment, and are shown to abut Cartref soils on the 1:100000 soils map (Fig. 3). The areas shown as Cartref soils on the $1: 100000$ scale map is dominated by Cartref types soils, but also include localized areas of other soil types including Longlands and Clovelly soils that could not be shown on a map of this scale. Thus, the Longlands and Clovelly soils shown on the detailed soils map extend further south and underlay a portion of the eastern hillslopes which drain into the wetland and the reservoir. It appears reasonable, then, that Longlands and Clovelly soils serve as the primary source of sand-sized sediment within the reservoir, particularly given the relatively steep slopes (4$7 \%$ ) upon which they occur.
The hillslopes underlain by Longlands and Clovelly soils are primarily covered by sugar cane. This is also consistent with the land-use based mixing model results which indicate that the majority of the sand-sized sediment was derived from cane fields.

Several loam-textured layers occur within the reservoir core (R1-C1) (Figs. 7 and 8). These finer-grained units were modeled to consist of sediment primarily derived from Katspruit, and to a much lesser degree, Cartref, Glencoe, and Avalon soils. As would be expected, Katspruit soils are rich in clay as are Avalon and Glencoe soils (although not to the degree of Katspruit soils) (Le Roux et al., 2006).

The Katspruit soils are primarily covered by vegetable fields on relatively flat sections of the valley bottom, and the land-use based modeling suggests that the loamy deposits within the reservoir are primarily derived from vegetable fields, with minor contributions from roads (with a clay-plinthic base) and cane fields (presumably underlain by Avalon or other clayey hillslope soil).

Similar texture, soil type, land-use associations occur within all three of the cores obtained from the wetland. These associations are particularly apparent for the lower portions of the deposits. For example, sediments within Core WT-C1 below approximately sample 10 exhibit a fine sandy-loam texture. Modeling suggests the sediments were derived from Katspruit soil (fine component) and Clovelly soils (sand component), covered primarily by vegetables and 
cane, respectively (Figs. 7 and 8). Finer grained deposits (loam textured) between samples 7-9 were derived, according to the model, from Katspruit and Westleigh soils (both fine grained) overlain by vegetables (including Maize, which can be found on Westleigh hillslopes).

A detailed examination of the modeling results indicates that a significant change in sediment source near the middle to top of the wetland and reservoir cores is superimposed on the texture, soil type, land-use association. In Core WT$\mathrm{C} 1$, the change in source begins at a depth of approximately $55 \mathrm{~cm}$ (sample 8) with a progressive increase in the contribution of sediment from pastures, wattles, and, to a much lesser degree, roads. Avalon and Longlands soil contributions also become more prevalent. The top of Core WT-C3 (above sample 6) also exhibits an increase in the contribution of sediment from wattle groves, and an increase in Longlands and Cartref soil types (the latter of which underlies wattle groves). In Core WT-C2, sediment above sample $10(62 \mathrm{~cm})$ is derived almost exclusively from areas composed of Katspruit soils and vegetable fields, with a rather abrupt input of material from roads. Further downstream in the reservoir, the change in source is characterized by an increase in sediment from wattle groves, and an increase in sediment from Glencoe soils.

Interestingly, changes in sediment source coincide with a notable increase in sedimentation rates from approximately 0.67 to $2.21 \mathrm{~cm} \mathrm{yr}^{-1}$ as determined using ${ }^{210} \mathrm{~Pb}$ data in Core WT-C1. The ${ }^{210} \mathrm{~Pb}$ data suggest that the change occurred between approximately 1988 and 1992.

The noted changes in sediment source and sedimentation may be related to (1) changes in land use and crop type through time, both in terms of the absolute area covered and their position on the landscape, and (2) changes in management strategies. It is more likely, however, that the alterations are associated with a major alteration in the geomorphic connectivity of headwater drainages that increased sediment delivery to the wetland and reservoir. Discussions with a local sugar cane farmer revealed that in the early 1990s, small areas of maize were changed to sugar cane. This would have involved contouring and water way development associated with cane, in order to limit off-site sediment yields.

At the time of the conversion of these maize fields to sugar cane, the valley bottom upstream of the cored wetland also consisted of a wetland that was consistently flooded, resulting in the deposition of sediment in an area which the farmer was attempting to pasture. Thus, a ditch was excavated through this wetland immediately upstream of the large tributary entering from the west (and which drains the wattle grove) (Fig. 5). The net result was an increase in geomorphic and hydraulic connectivity that allowed drainage from the fields within the headwater areas of the catchment and the western tributary to be transported further downstream. The change appears as (1) an increase in sedimentation rates in Core WT-C1, and (2) an increase in sediment from the wattles and Cartref soils from the tributary, as well as a road that previously limited downstream drainage. The increased contribution of sediment from pastures, present in Core WT-C1, is probably due to bank erosion along the excavated ditch.

Core WT-C2 exhibits a significant increase in sediment from vegetable fields underlain by Katspruit soils, at the expense of sediment from cane fields. Given the conversion of some maize fields to sugar cane upstream of the cored wetland around 1990, the change in sediment provenance is surprising. However, it may be related to better sediment control practices on the cane fields which allowed a larger proportion of the sediment to be derived from the vegetable plots (primarily cabbage). It is also important to remember that sediment source is texture dependent, so that the contribution of sand-sized sediment from the cane fields was shown to increase within Cores WT-C3 and WT-C1 as a result of the drainage alteration.

It is significant to note that the relative contributions to the cored wetland and reservoir as determined from the mixing model cannot be quantitatively extrapolated to lowersubcatchment areas. Ideally, we would have performed the analysis on other downstream depositional environments, but financial constraints, particularly the costs of analyzing a larger number of upland samples, inhibited our ability to do so. We suspect that the relative contributions of sediment from the defined sediment sources will change along the valley to a limited degree as a result of (1) minor changes in the spatial distribution of primary soil and land-use types between the upper, middle, and lower subcatchments, (2) sediment storage within downstream reservoirs, and (3) differences in the relative percentage of runoff contributed to the channel from the upper, middle, and lower subcatchment areas. With regards to the latter, stable isotopic data $(\mathrm{H}, \mathrm{O})$ show that between 22 and $75 \%$ of the discharge in the channel near the coring site within the lower subcatchment is derived from basin areas located downstream of the reservoirs. These isotopic data suggest that a non-negligible portion of the sediment is likely to be derived from downstream areas during at least some flows.

While the relative percentages of sediment derived from each source may change along the channel, the primarily conclusions put forth earlier are likely to apply to the entire catchment that was studied. These conclusions include (1) that fine-grained sediment within the wetlands and reservoirs are primarily derived from fine-grained lowland soils frequently used for vegetable plots and/or, in downstream areas, pastures, (2) that sand-sized sediment is geochemically distinct from sampled fine-grained sediment, and is predominantly derived from coarse-textured soils found on steep slopes, (3) that the coarser sand-sized particles are transported to and through the drainage system during relatively moderate to high magnitude runoff events, and (4) that the construction of a ditch through the upstream most wetland led to a significant and abrupt change in the source of sediment to all downstream areas of the drainage system. 


\subsection{Insights into geomorphic connectivity from other geochemical tracers}

Several trace elements provide useful information regarding the downvalley transfer of sediment within the entire section of the studied catchment. The two of most importance are $\mathrm{Cu}$ and $\mathrm{Zn}$. Both elements are contained in fertilizer known to have been used on vegetable fields (cabbage, maize) predominantly located within the upper subcatchment (Fig. 2). In fact, the utilized fertilizer is reported (on its bag) to contain $2.5 \% \mathrm{Zn}$. The potential impact of the fertilizer on $\mathrm{Zn}$ concentrations in the soil is illustrated by comparing the amount of $\mathrm{Zn}$ within pasture and vegetable fields underlain by the same soil type (Katspruit). The pasture samples exhibit a mean $\mathrm{Zn}$ concentration of $3.58 \mu \mathrm{g} \mathrm{g}^{-1}$, compared to a concentration of $139 \mathrm{\mu g} \mathrm{g}^{-1}$ for the vegetable plots, the latter higher by two orders of magnitude (Fig. 10). In addition, $\mathrm{Zn}$ concentrations within soils of the vegetable plots are much higher than is generally observed for uncontaminated bedrock (16-105 $\mu \mathrm{g} \mathrm{g}^{-1}$ ) or soils $\left(60 \mu \mathrm{g} \mathrm{g}^{-1}\right)$, (Turekian, 1971; Buonicore, 1996; Miller and Orbock Miller, 2007). Similar trends are found for $\mathrm{Cu}$, although differences between background materials and the vegetable plots are not as significant (Fig. 10).

$\mathrm{Cu}$ and $\mathrm{Zn}$ concentrations within the wetland cores vary systematically with depth, but the trends are distinctly different (Fig. 11). Variations in observed trends can be explained, however, by differences in sediment provenance. In Core WT-C1, for example, both $\mathrm{Cu}$ and $\mathrm{Zn}$ concentrations increase from the bottom of the core toward the surface (from samples 16 to 7). The concentrations then abruptly decrease by a factor of 5 before remaining relatively constant until reaching the ground surface. The change in concentration is coincident with the observed increase in sedimentation rates (discussed early), and a change in sediment sources documented by the mixing model. More specifically, $\mathrm{Zn}$ and $\mathrm{Cu}$ concentrations tend to increase as contributions from vegetable fields increase, and decrease as contributions from pastures and cane fields increase (compare Figs. 8 and 11). The influence of sediment provenance on $\mathrm{Cu}$ and $\mathrm{Zn}$ concentrations within the cores is illustrated more directly in Fig. 12. With the exception of three outliers (discussed below), there is a weak tendency for $\mathrm{Zn}$ and $\mathrm{Cu}$ concentrations to increase as the modeled contribution of sediment from vegetable fields increases. In contrast, inverse relations exist for cane and pasture. The dramatic decrease in concentration above sample 7 in Core WT-C1 can therefore be explained by (1) increasing contributions of sediment from pasture and cane fields, and (2) higher rates of sand-sized particle sedimentation which presumable exacerbated the effects of dilution on $\mathrm{Cu}$ and $\mathrm{Zn}$ concentrations.

In contrast to Core WT-C1, contributions of sediment from vegetable fields in Core WT-C2 increase toward the surface (decreasing age) above sample 12 (Fig. 11). As expected from the paragraph above, concentrations of $\mathrm{Cu}$ and $\mathrm{Zn}$ increase as the contributions of sediment from vegetable fields (a)

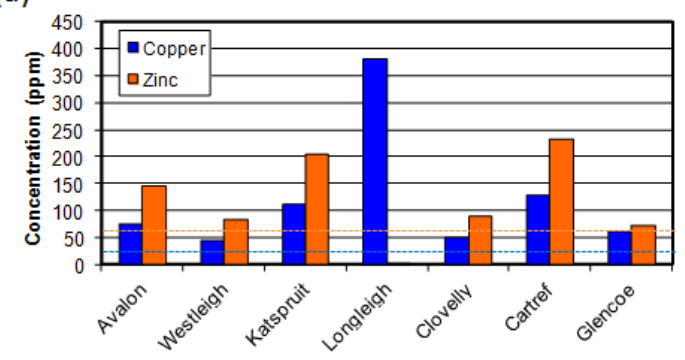

(b)

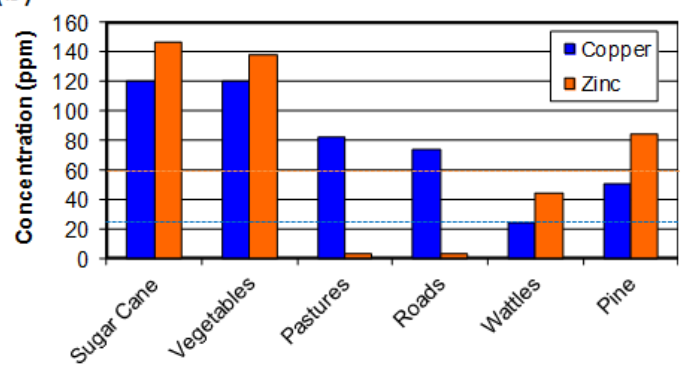

Fig. 10. Mean concentrations of $\mathrm{Cu}$ and $\mathrm{Zn}$ calculated for (a) upland soil and (b) land use. Dashed lines represent global average $\mathrm{Cu}$ (blue) and $\mathrm{Zn}$ (orange) concentrations within soil reported by Buonicore (1996).

increase. It is also notable that the lowest $\mathrm{Cu}$ and $\mathrm{Zn}$ concentrations are associated with sample 12 which the source model suggests contains the most sediment from the cane fields.

The indirect relationship between $\mathrm{Cu}$ and $\mathrm{Zn}$ concentrations and the relative contribution of sediment from pastures is understandable given the limited use of fertilizer on pastures. However, the indirect relationship between $\mathrm{Cu}-\mathrm{Zn}$ concentrations and sediment from cane fields is surprising given the relatively high mean concentrations of the two elements in cane field samples (Fig. 10b). This inverse relationship may be related the use of fertilizers on maize fields which were later converted into cane. This hypothesis is supported by (1) highly variable $\mathrm{Cu}$ and $\mathrm{Zn}$ concentrations within samples collected from the cane fields, and (2) $\mathrm{Cu}$ and Zn concentrations in a few samples that exceed those typically found in soil and bedrock (Fig. 10). The hypothesized influx of sediment to the wetland from previously fertilized cane fields with high $\mathrm{Cu}$ and $\mathrm{Zn}$ concentrations would also explain the outliers on Fig. 12 (high $\mathrm{Cu}$ and $\mathrm{Zn}$ with no significant input of sediment from vegetable fields, and high $\mathrm{Cu}$ and $\mathrm{Zn}$ with high input from cane fields and pastures).

The difference in $\mathrm{Cu}$ and $\mathrm{Zn}$ concentrations in Longlands soils is interesting as the parent material for it is thought to be the same as that for the other soil types in the catchment (Natal Group Sandstones). Moreover, if the high $\mathrm{Cu}$ concentrations consistently observed for Longlands soil samples were related to fertilizer, high $\mathrm{Zn}$ concentration would also be expected as shown on Fig. 11. It is unclear at this 


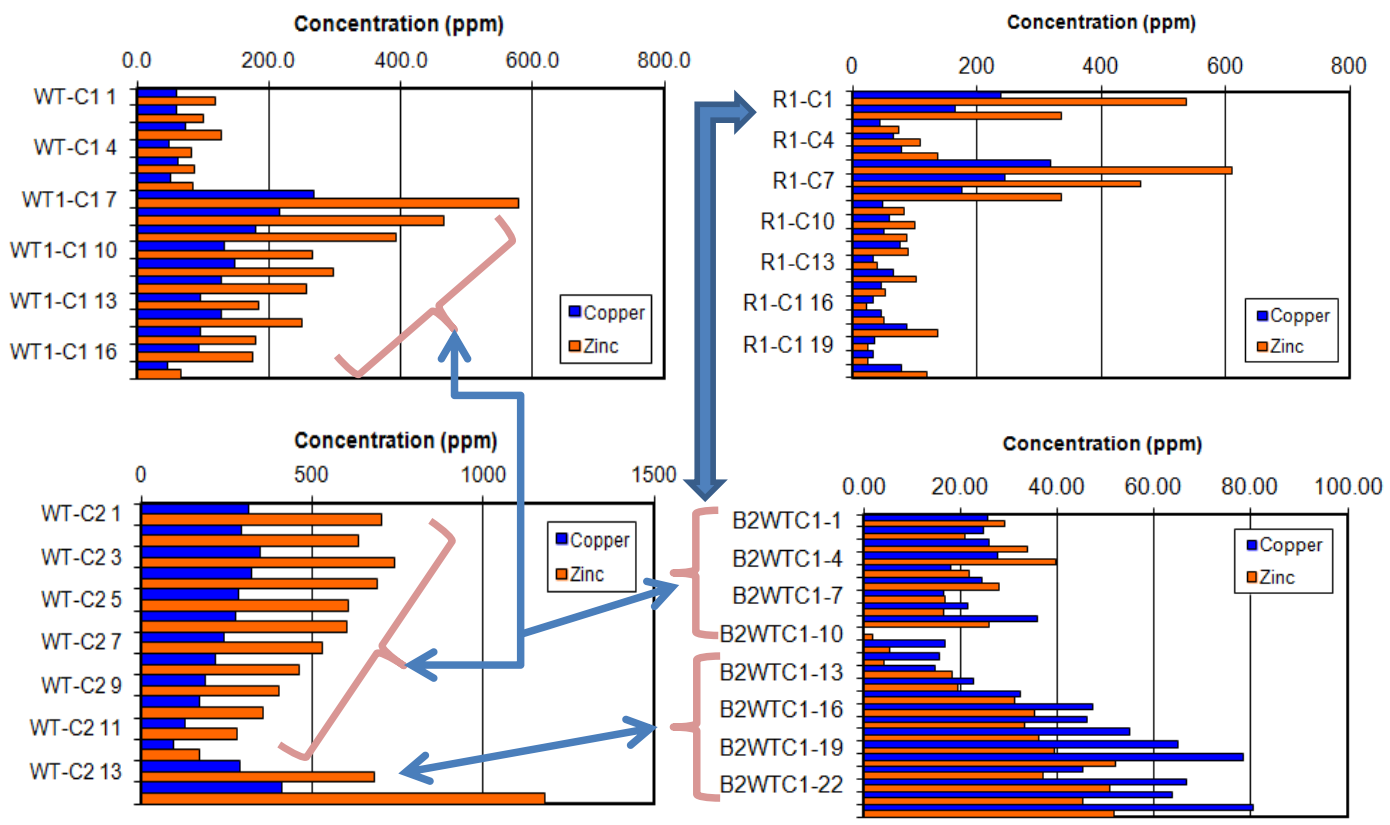

Fig. 11. Variations in $\mathrm{Cu}$ and $\mathrm{Zn}$ concentrations with depth in wetland Cores WT-C1 (a), WT-C2 (b), R1C1 (c), and B2WTC1 (d).

time why such large differences exist, when they do not for the other soil types. It is possible, however, that the sandy nature of Longlands soils, combined with their occurrence on relatively steep slopes, allowed the more mobile $\mathrm{Zn}$ to be leached from the sampled surface sediments.

Figure 11 shows that $\mathrm{Cu}$ and $\mathrm{Zn}$ concentrations are relatively low from the bottom of Core R1-C1 (sample 21 to sample 9). Concentrations of both elements above sample 9 are generally 3 to 5 fold higher. The change in concentrations is roughly coincident with the modeled change in sediment provenance that was attributed earlier to the construction of a drainage ditch through an upstream wetland. In other words, higher $\mathrm{Cu}$ and $\mathrm{Zn}$ concentrations appear to result from an increase in system connectivity and the capacity for sediment derived from headwater vegetable fields and other sediment sources to be transported downstream through the wetlands and to the reservoir.

Interestingly, Cores WT-C2 and B2WTC1 exhibit similar depth trends in $\mathrm{Cu}$ and $\mathrm{Zn}$ concentrations to that observed for approximately the top third of R1-C1 (Fig. 11b-d). Concentrations are high at the surface and then systematically decrease with depth before increasing further down the core. The primary difference is that the abrupt decrease in $\mathrm{Cu}$ and $\mathrm{Zn}$ concentrations (and their subsequent uniform distribution) observed at depth within Core R1-C1 is not present in the other two cores. The zone of relatively low $\mathrm{Cu}$ and $\mathrm{Zn}$ concentrations corresponds sedimentologically to layers containing significant amounts of sand-sized sediment which the source modeling indicates was derived in part from cane fields. The $\mathrm{Cu}$ - and $\mathrm{Zn}$-enriched horizons are finer grained and derived predominantly from vegetable plots in Cores
WT-C2 and R1-C1 (as noted earlier, source modeling was not performed on Core B2WTC1 because it was located well downstream of the sampled upland sediment sources). The similarities in depth trends in concentration suggest that all three locations, spanning the entire study catchment, received sediment with similar $\mathrm{Cu}$ and $\mathrm{Zn}$ concentrations since about 1990. Because these two elements are primarily associated with soil amendments used on vegetable fields concentrated in headwater areas, the observed similarities in elemental concentrations as a function of depth within cores from the upper subcatchment wetland, the middle subcatchment reservoir, and the lower subcatchment riparian wetland suggest that sediment was transported through the drainage system during runoff events. Thus, some degree of geomorphic connectivity must have existed. It therefore appears that following the construction of the upstream drainage ditch through the upstream wetland, the axial drainage network was geomorphically and hydrologically connected.

\subsection{Sediment sources, runoff magnitudes, and basin connectivity}

Geochemical provenance studies show that the source of sediment deposited within wetlands of the upper subcatchment, and a reservoir from the middle subcatchment, varies as a function of sediment size, stratigraphic layer, and time of deposition. Fine-grained sediment within both depositional settings was primarily derived from vegetable fields underlain by fine-grained soils (e.g., Katspruit) that comprise the valley floor. It seems reasonable to assume that these sediments were delivered to the axial drainage network during relatively modest storm events when hillslope runoff over 

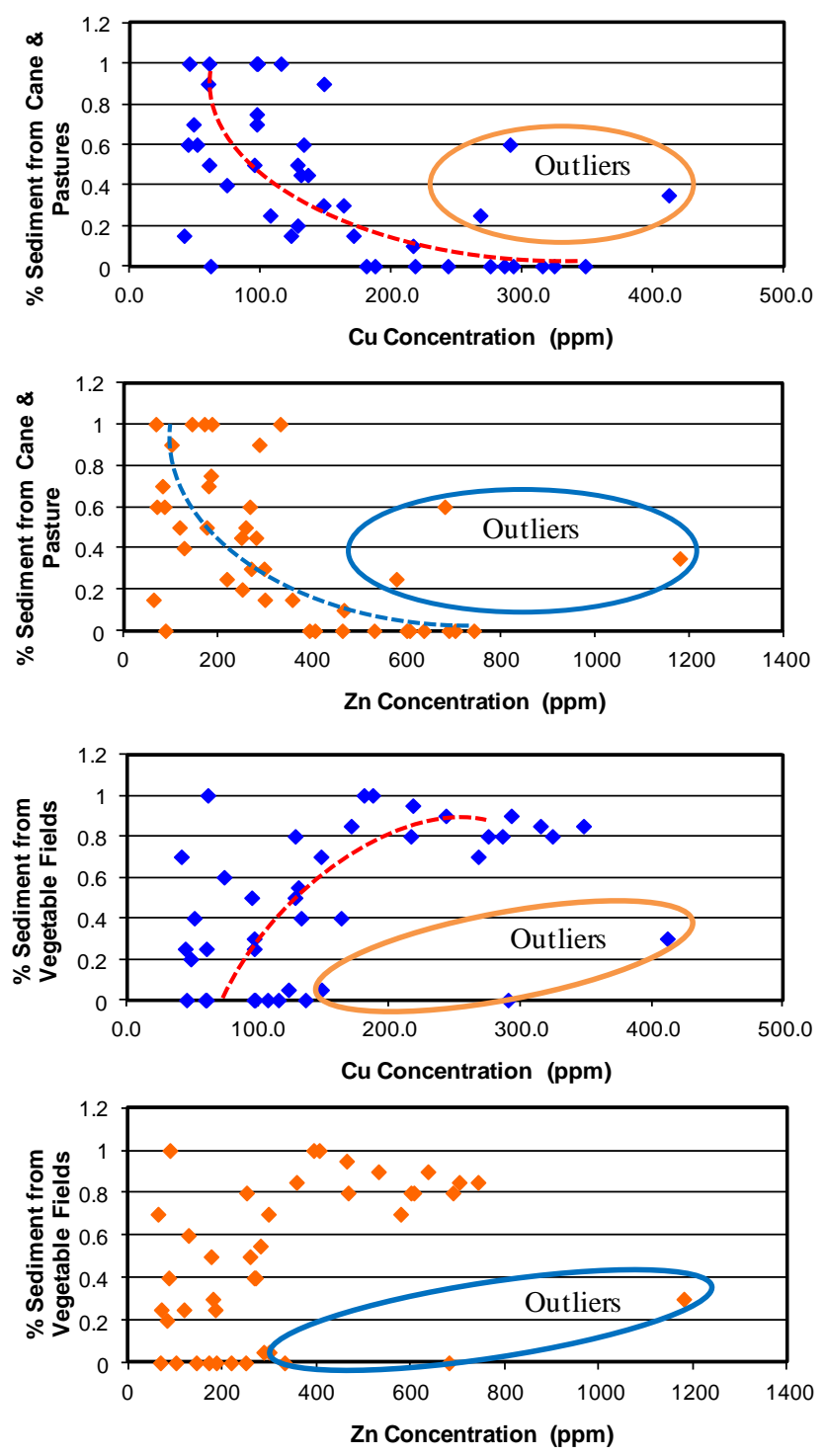

Fig. 12. Relationship between $\mathrm{Cu}$ and $\mathrm{Zn}$ concentrations and percent relative contribution from vegetable and pasture plus cane fields.

sandier soils with higher infiltration capacities was limited (Fig. 13). In other words, the lack of sandier sediments from cane fields on hillslopes within the wetland deposits suggests that the hillslopes were not significantly eroded during relatively low-magnitude events. Alternatively, what sediment was eroded was redeposited on the hillslopes as a result of the utilized management practices.

Very little of the fine-grained sediment from low-lying vegetable fields was deposited and stored with the first downstream reservoir of the middle subcatchment. The general lack of fine-sediment within the reservoir is presumably related to (1) the hydrologically and geomorphologically disconnected nature of the drainage network during low-flow conditions (prior to valley floor modification), and (2) the minimal impact of the dams on the storage of silt- and claysized particles during larger events when the system is hydrologically connected. The lack of influence of the dams on sediment storage is not surprising given that water overflows the dams during periods of high surface runoff, creating a rapidly flowing system through the reservoir, and the increase in sediment transport capacity of the middle subcatchment (as described below).

Sandier sediments within both the wetland and the reservoir were derived largely from hillslope cane fields. Presumably, these sediments were not only eroded from the valley bottom sediment sources, but from sandier hillslope soils covered largely by sugar cane during larger storm events that produced significant runoff. What is important to recognize is that the provenance of the sediment within the examined depositional environments varied as a function of both sediment size and runoff magnitude. Moreover, given the chemically reactive nature of fine-particles, and the association of nutrients, particularly phosphate, with sediment, reductions in sediment-associated nutrient loads may best be sought through practices that address the erosion of sediment from agricultural fields along the valley floor.

The above provenance studies, combined with data from the geomorphic investigations, show that the Mkabela Basin, and presumably other similar catchments within the KwaZula-Natal Midlands, can be subdivided into three geomorphologically distinct subcatchments. These subcatchments vary in relief, the nature of their drainage network (or process zones) and their ability to store and transport sediment. As a result, sediment transport and storage do not systematically vary along the axial drainage system, but are characterized by spatially abrupt changes in their nature and magnitudes. In headwater areas with intact valley floors, sediment eroded predominantly from low-lying areas during low-magnitude events are largely deposited within wetlands that comprise large segments of the valley floor. The general lack of fine sediment within the reservoir, prior to valley modification, suggests that while the axial drainage network may be integrated during large floods, during low to moderate events the upper catchment areas were disconnected from downstream sections of the catchment (Fig. 14). Thus, the wetlands (in their natural state) serve as reservoirs of sediment (and associated nutrients).

In contrast to the upper subcatchments, the mid-catchment areas are dominated by relatively high gradient alluvial and bedrock channels, with fewer, natural depositional zones. This portion of the catchment, then, possesses a greater ability to transport sediment downstream effectively (Fig. 14). The general lack of fine sediment within the reservoirs indicates that once silt- and clay-sized sediment is entrained, it is transported through this section of the catchment, although at least some of the transported material may be stored on or within floodplains that are more extensive than they are upstream. 


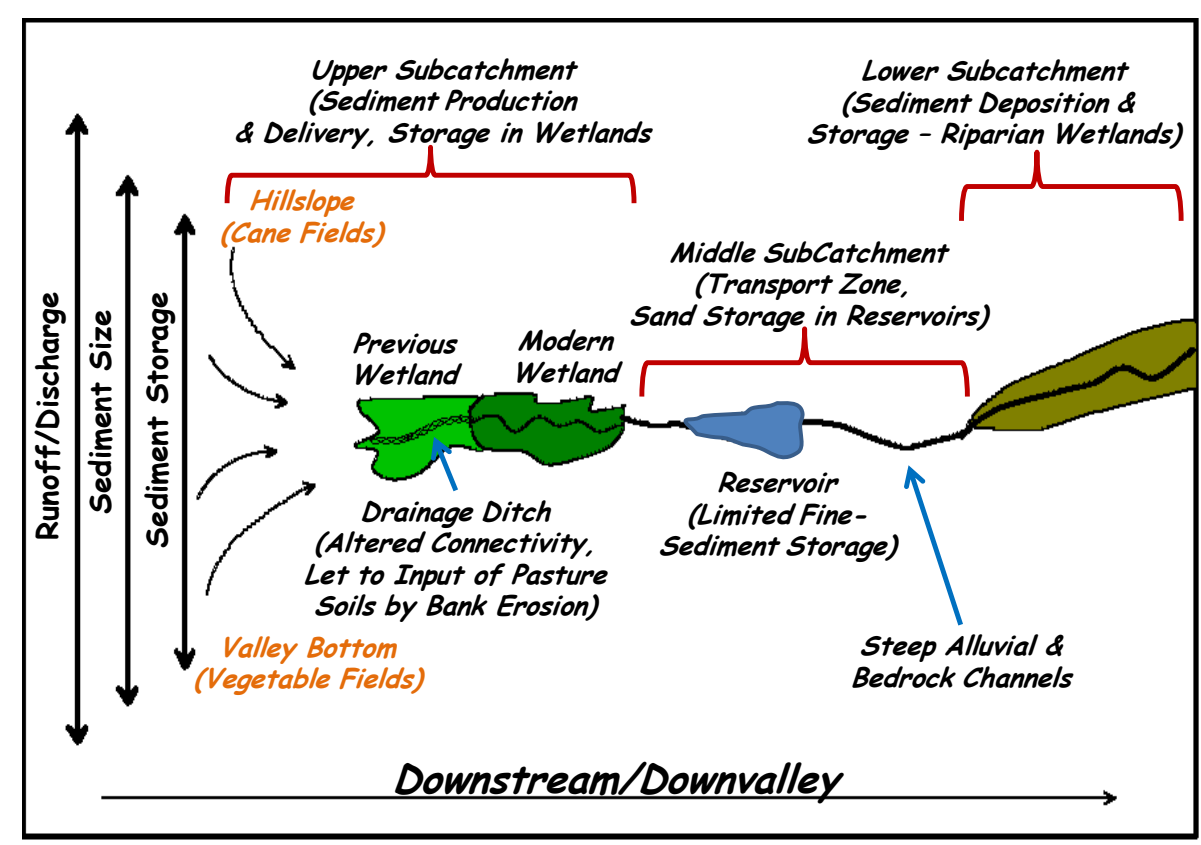

Fig. 13. Schematic diagram of the primary processes occurring in each of the three delineated subcatchments, and the variations in sediment size and source from varying runoff magnitudes.

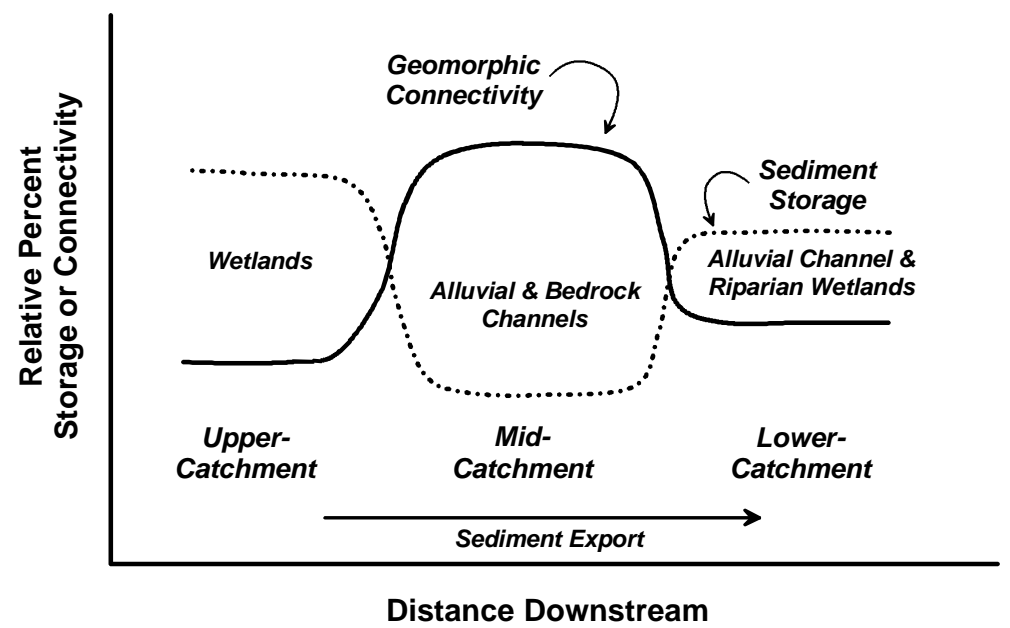

Fig. 14. Schematic diagram illustrating differences in geomorphic connectivity and sediment storage between subcatchment zones of the Mkabela Basin.

The lower subcatchment is dominated by low gradient, alluvial channels boarded by extensive riparian wetlands. Storage of sediment within this zone is extensive, as illustrated by Core B2WTC1, once again limiting the downstream translation of sediment and nutrients that they may carry (Fig. 14). The natural division of the catchment into geomorphologically distinct sections suggests that previously developed watershed modeling routines that are used to predict sediment exports from a basin may need to be modified before being applied to these catchments adequately to address the abrupt changes in sediment transport processes that occur.

\section{Conclusions}

The source, transport, and storage of sediment was evaluated within the Mkabela Catchment using a combination of geomorphic, hydrologic, and geochemical tracing analyses. The integrated approach resulted in the following conclusions.

1. The Mkabela Basin, and other similar catchments within the KwaZulu-Natal Midlands, exhibit three distinct morphological areas (referred to as upper, middle, and lower subcatchments), each characterized by differences in its ability to produce, transfer, and store 
sediment. Upper catchment areas are characterized by extensive wetlands along the valley floor which, in their natural state, represent significant sediment sinks. Mid-catchment areas are characterized by less extensive riparian wetlands, and possess higher-gradient alluvial and bedrock channels conducive to sediment transport. Lower catchment areas are characterized by lowergradient alluvial valley floors, incised into the surrounding terrain, that possess broad riparian wetlands that store considerable quantities of sediment and associated nutrients.

2. The complex interactions between runoff, soil type and characteristics, and land use (among other factors) create temporal and spatial variations in sediment provenance. Silt- and clay-rich layers found within the wetland and reservoir deposits are derived from the erosion of fine-grained, valley bottom soils which are frequently utilized as vegetable fields. The deposits tend to exhibit elevated concentrations of $\mathrm{Cu}$ and $\mathrm{Zn}$, presumably from the use of fertilizers which contain both elements. Coarser-grained sediments within the wetland and reservoir environments are derived from the erosion of sandier hillslope soils extensively utilized for sugar cane. Erosion of these upland cane fields presumable occurs during relatively high magnitude runoff events that are capable of transporting sand-sized sediment off the slopes. Therefore, sediment source varies as a function of particle size and runoff magnitude.

3. Sediment source determination, carried out on multiple cores from the wetland, demonstrated that sediment partitioning by particle size occurs during transport producing deposits of varying sedimentological and chemical characteristics. While general provenance characteristics (e.g., the fact that fine sediment was derived from specific soils used primarily for vegetable fields) were similar between the cores, differences in sediment provenance as a function of depth (time) exist. As a result, within highly variable depositional environments, multiple cores should be collected and analyzed fully to determine sediment provenance from non-point sources.

4. Comparison of sediment provenance between sites and through time revealed that the construction of a drainage ditch through the upstream-most wetland significantly altered the geomorphic and hydrologic connectivity of the catchment. Prior to its construction, sediments (and the nutrients that they carry) were largely deposited within wetlands which encompassed a majority of the valley floors within the upper catchment. Thus, upper catchment areas were disconnected from mid- and lower-subcatchment areas during most flood events. Following construction of the ditch, sediments from the upper catchment were transported to and through mid-catchment areas and were subsequently accumulated to significant thicknesses within riparian wetlands of the lower catchment.

5. The construction of the drainage ditch through the wetland appears to have negated some of the effectiveness of best management practices that are used on the cane fields to limit sediment and nutrient losses from the hillslopes.

Acknowledgements. Funding for this project was provided by a grant from the National Science Foundation under award No. \#20060107, and the Whitmire Endowment at Western Carolina University. Their support is greatly appreciated. The support of the Water Research Commission of South Africa and the farmers of the Noodsberg Cane Growers' Association also is gratefully acknowledged.

Edited by: A. Bronstert

\section{References}

Appleby, P. G. and Oldfield, F.: The calculation of ${ }^{210} \mathrm{~Pb}$ dates assuming a constat rate of supply of unsupported ${ }^{210} \mathrm{~Pb}$ to the sediment, Catena, 5, 1-8, 1978.

Bottrill, L. J., Walling, D. E., and Leeks, G. J. L.: Using recent overbank deposits to investigate contemporary sediment sources in larger river basins, in: Tracers in geomorphology, edited by: Foster, I. D. L., Wiley, Chichester, 369-387, 2000.

Brierley, G. J. and Fryirs, K.: Variability in sediment delivery and storage along river courses in Bega catchment, NSW, Australia: implications for geomorphic river recovery, Geomorphology, 38, 237-265, 2001.

Brierley, G. J. and Fryirs, K. A.: Geomorphology and River Management: Applications of the River Styles Framework, Blackwell Publishers, Oxford, UK, 2005.

Buonicore, A. J.: Cleanup criteria for contaminated soil and groundwater: 1996 edition, American Society for Testing and Materials, West Conshohocken, PA, 1996.

Collins, A. L.: The use of composite fingerprints for tracing the source of suspended sediment in river basins, Unpublished $\mathrm{PhD}$ Thesis, University of Exceter, 1995.

Collins, A. L., Walling, D. E., and Leeks, G. J. L.: Use of the geochemical record preserved in floodplain deposits to reconstruct recent changes in river basin sediment sources, Geomorphology, 19, 151-167, 1997a.

Collins, A. L., Walling, D. E., and Leeks, G. J. L.: Source type ascription for fluvial suspended sediment based on a quantitative composite fingerprinting technique, Catena, 29, 1-27, 1997b.

Collins, A. L., Walling, D. E., and Leeks, G. J. L.: Use of composite fingerprints to determine the provenance of the contemporary suspended sediment load transported by rivers, Earth Surf. Proc. Land., 23, 31-52, 1998.

Douglas, G., Palmer, M., and Caitcheon, G.: The provenance of sediments in Moreton Bay, Australia: a synthesis of major, trace element and $\mathrm{Sr}-\mathrm{Nd}-\mathrm{Pb}$ isotopic geochemistry, modeling and landscape analysis, Hydrobiologia, 494, 145-152, 2003. 
Douglas, G., Ford, P., Palmer, M., Noble, R., and Packett, R.: Identification of sediment sources in the Fitzroy River Basin and Estuary, Queensland, Australia Nutrient and carbon cycling in subtropical estuaries Fitzroy - FH1, in: Focus: Coastal science for the Fitzroy region, edited by: Noble, R., Bell, R., Tilden, A., and Fitzroy, J., CRC for Coastal Zone Estuary and Waterway Management, 18-19, 67-72, 2005.

Douglas, G., Kuhnen, M., Radke, L., Hancock, G., Brooke, B., Palmer, M., Pietsch, T., Ford, P., Trefry, M., and Packett, R.: Delineation of sediment sources to a coastal wetland in the Great Barrier Reef catchment: Influence of climate variability and land clearing since European arrival, Environ. Chem., 7, 190-206, 2010.

Foster, I. D. L., Boardman, J., and Keay-Bright, J.: Sediment tracing and environmental history for two small catchments, Karoo uplands, South Africa, Geomorphology, 90, 126-143, 2007.

Foster, I. D. L., Rowntree, K. M., Boardman, J., and Mighall, T. M.: Changing sediment yield and sediment dyanmics in the Karoo Uplands, South Africa; Post-European impacts, Land Degrad. Dev., 23, 508-522, 2012.

Frissell, C. A., Liss, W. J., Warren, C. E., and Hurley, M. D.: A hierarchical framework for stream habitat classification: viewing streams in a watershed context, Environ. Manage., 10, 199-214, 1986.

Grant, G. E., Swanson, F. J., and Wolman, M. G.: Pattern and origin of stepped-bed morphology in high-gradient streams, western Cascades, Oregon, Geol. Soc. Am. Bull., 102, 340-352, 1990.

Grant, G. E., Swanson, F. J., Costa, J. E., Miller, A. J., Potter, K. W., Wilcock, P. R. (Eds.): Morphology and processes of valley floors in mountain streams, western Cascades, Oregon, Natural and Anthropogenic Influences in Fluvial Geomorphology, American Geophysical Union Monograph 89, Washington, DC, 83$102,1995$.

Hooke, J.: Coarse sediment connectivity in river channel systems: a conceptual framework and methodology, Geomorphology, 56, 79-94, 2003.

Kishi, T., Mori, A., Hasegawa, K., and Kuroki, M.: Bed configurations and sediment transports in mountainous rivers, in: Comparative Hydrology of Rivers of Japan, Final Report, Japanese Research Group of Comparative Hydrology, Hokkaido University, Sapporo, Japan, 165-176, 1987.

Le Roux, P., Fraenkel, C. H., Bothma, C. B., Gutter, J. H., and Du Preez, C. C.: Soil Survey Report: Mkabela Catchment, Report for the Water Research Commision, Pretoria, 2006.

Lorentz, S., Miller, J., Lechler, P., Mackin, G., Lord, M., Kollongei, J., Pretorius, J., Ngeleka, K., Zondi, N., and Le Roux, J.: Definition of process zones and connectivity in catchment scale NPS processes, WRC Research No. 1808/1/11, Water Research Commission, Pretoria, 2011.
Miller, J. R. and Orbock Miller, S. M.: Contaminated River: A Geomorphological-Geochemical Approach to Site Assessment and Remediation, Springer, Berlin, 2007.

Miller, J. R., Lord, M., Yurkovich, S., Mackin, G., and Kolenbrander, L.: Historical trends in sedimentation rates and sediment provenance, Fairfield Lake, western North Carolina, J. Am. Water Resour. Assoc., 41, 1053-1075, 2005.

Miller, J. R., Lord, M., Villarroel, L. F., Germanoski, D., and Chambers, J.: Structural Organization of Process Zones in Upland Watersheds of Central Nevada and Its Influence on Basin Connectivity, Dynamics, and Wet Meadow Complexes, Geomorphology, 139-140, 384-402, 2012.

Montgomery, D. R. and Buffington, J. M.: Channel classification, prediction of channel response, and assessment of channel conditions, Report TFW-SH10-93-002, Washington State Timber, Fish, and Wildlife, Pullman, WA, 1993.

Nash, J. E. and Sutcliffe, J. V.: River flow forecasting through conceptual models 1, a discussion of principles, J. Hydrol., 10, 282 290, 1970.

Rowan, J. S., Goodwill, P., and Franks, S. W.: Uncertainty estimation in fingerprinting suspended sediment sources, in: Tracers in Geomorphology, edited by: Foster, I. D. L., John Wiley and Sons, 279-289, 2000.

Russell, M. A., Walling, D. E., and Hodgkinson, R. A.: Suspended sediment sources in two small lowland agricultural catchments in the UK, J. Hydrol., 252, 1-24, 2001.

Slattery, M. C., Burt, T. P., and Walden, J.: The application of mineral magnetic measurements to quantify within-storm variations in suspended sediment sources, in: Tracer Technologies for Hydrological Systems, IAHS Publication No. 229, edited by: Leibundgut, C. H., IAHS Press, Wallingford, 143-151, 1995.

Turekian, K. K.: Elements, geochemical distribution of, in: Encyclopedia of Science and Technology, McGraw-Hill, New York, 1971.

USEPA: National water quality inventory: 2000 report, EPA-841-R02-001, National Service Center for Environmental Publications, Washington, DC, 2000.

Walling, D. E., Owens, P. N., and Leeks, G. J. L.: Fingerprinting suspended sediment sources in the catchment of the River Ouse, Yorkshire, UK, Hydrol. Process., 13, 955-975, 1999.

WRC: State-of-Rivers Report uMngeni River and neighbouring rivers and streams, WRC report no. TT 200/02, Water Research Commission, Pretoria, 2002.

Yu, L. and Oldfield, F.: A multivariate mixing model for identifying sediment source from magnetic measurements, Quaternary Res., 32, 168-181, 1989. 